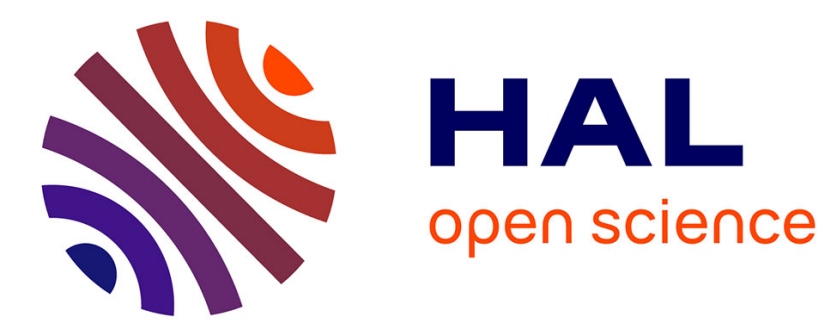

\title{
New transcriptomic tools to understand testis development and functions
}

Estelle Lecluze, Bernard Jégou, Antoine D. Rolland, Frédéric Chalmel

\section{To cite this version:}

Estelle Lecluze, Bernard Jégou, Antoine D. Rolland, Frédéric Chalmel. New transcriptomic tools to understand testis development and functions. Molecular and Cellular Endocrinology, 2018, 468, pp.47-59. 10.1016/j.mce.2018.02.019 . hal-01864339

HAL Id: hal-01864339

\section{https://hal-univ-rennes1.archives-ouvertes.fr/hal-01864339}

Submitted on 30 Aug 2018

HAL is a multi-disciplinary open access archive for the deposit and dissemination of scientific research documents, whether they are published or not. The documents may come from teaching and research institutions in France or abroad, or from public or private research centers.
L'archive ouverte pluridisciplinaire HAL, est destinée au dépôt et à la diffusion de documents scientifiques de niveau recherche, publiés ou non, émanant des établissements d'enseignement et de recherche français ou étrangers, des laboratoires publics ou privés. 


\section{New transcriptomic tools to understand testis development and functions}

Estelle Lecluze ${ }^{1}$, Bernard Jégou ${ }^{1}$, Antoine D. Rolland ${ }^{1, \dagger}$, Frédéric Chalmel ${ }^{1, \dagger, *}$

${ }^{1}$ Univ Rennes, Inserm, EHESP, Irset (Institut de recherche en santé, environnement et travail) UMR_S1085, F-35000 Rennes, France

*Corresponding author

$\dagger$ These authors contributed equally to this work

Contact: frederic.chalmel@inserm.fr

\section{Abstract}

The testis plays a central role in the male reproductive system - secreting several hormones including male steroids and producing male gametes. A complex and coordinated molecular program is required for the proper differentiation of testicular cell types and maintenance of their functions in adulthood. The testicular transcriptome displays the highest levels of complexity and specificity across all tissues in a

15 wide range of species. Many studies have used high-throughput sequencing technologies to define the molecular dynamics and regulatory networks in the testis as well as to identify novel genes or gene isoforms expressed in this organ. This review intends to highlight the complementarity of these transcriptomic studies and to show how the use of different sequencing protocols contribute to improve our global understanding of testicular biology.

\section{Keywords}

Testis; development; spermatogenesis; germ cells; RNA-sequencing; transcriptomics

\section{Highlights}

RNA-sequencing applied to testis biology

\section{Abbreviations}

BS-seq: bisulfite sequencing

CB: chromatoid body

ceRNAs: competing endogenous RNA 
ChIP-seq: chromatin immunoprecipitation followed by sequencing circRNA: circular RNA

Dpc: days post coitum

Dpp: days post partum

5 EST: Expressed Sequenced Tag

GCs: germ cells

lncRNA: Long noncoding RNA

miRNA: micro RNA

NOMe-seq: nucleosome occupancy and DNA methylation profiling followed by sequencing

10 PGCs: primordial germ cells

PGCLCs: PGC like cells

piRNA: Piwi interacting RNA

RNA-seq: RNA sequencing

rRNA ribosomal RNA

15 SAGE: serial analysis of gene expression

scRNA-seq: Single-cell RNA sequencing

siRNA: small interfering RNA

sncRNA: small noncoding RNA

Spc: spermatocytes

20 Spg: spermatogonia

Spt: spermatids

Spz: spermatozoa

SSCs: spermatogonial stem cells

UHTS: ultra-high-throughput sequencing 


\section{Introduction}

The transcriptome can be defined as the entire set of transcripts present in a given biological sample. For a long time, the central dogma in molecular biology assumed that one gene is transcribed into one messenger RNA (mRNA) which in turn is translated into one protein that fulfills various structural,

5 biological and/or regulatory functions within the cell. However, it is now clear that the transcriptome is a far more complex machinery, composed by several RNA classes performing a myriad of functions. About two thirds of human genes contain more than one alternatively spliced exon (Johnson et al., 2003) and are thus able to produce numerous RNA and protein isoforms. A large part of the transcriptome is also composed of RNAs that do not encode proteins - noncoding RNAs (ncRNAs). These are involved in a

10 wide variety of biological processes (for review, see: Cech and Steitz, 2014), including testis differentiation/development (Rastetter et al., 2015; Taylor et al., 2015) and spermatogenesis (Luk et al., 2014). Long noncoding RNAs (lncRNAs) constitute the first class of noncoding transcripts, longer than 200bp, and are involved in many regulatory mechanisms, such as transcriptional, post-transcriptional and direct protein activity regulation (Wang and Chang, 2011). Small noncoding RNAs (sncRNAs) refer to transcripts shorter than 200bp that can be further divided into micro RNAs (miRNAs), small interfering RNAs (siRNAs) or Piwi interacting RNAs (piRNAs), most of which regulate gene expression at a transcriptional and/or post-transcriptional level (for review, see : Luo et al., 2016). Capturing all types of RNA species is necessary to fully understand the transcriptional network at play within a given cell. Owing to the intrinsic structural differences between mRNAs, IncRNAs and sncRNAs, transcriptomic studies typically focus on a single type of RNA. These intrinsic differences also warrant specific extraction methods, sequencing protocols and distinctive analytical strategies.

The first transcriptomic technology, called Expressed Sequenced Tag (EST), was based on the Sanger method and consisted of partial sequencing of cDNAs cloned into bacterial plasmids. The serial analysis of gene expression (SAGE) (Velculescu et al., 1995) was an improved version of the EST

25 technique that allowed increasing the sequencing throughput as well as quantifying the corresponding transcripts. Both EST and SAGE technics already introduced the notion of transcript assembly (tags concatenated into contigs) prior to association of corresponding genes in a reference genome. While these methodologies paved the way to decipher transcriptomes, they remained resource, time and money consuming. The technology that allowed transcriptomics to truly become a high-throughput discipline was DNA microarrays. These consist of solid surfaces on which DNA fragments, called probes, are spotted or synthetized in situ (Heller, 2002; Nelson, 2001; Pozhitkov et al., 2007; Schena et al., 1995). The complementary sequence between probes and transcripts (or corresponding cDNAs) allows their specific hybridization, while radioactivity or fluorescence intensity emitted following hybridization is used for 
quantification purposes. The design of probes is critical and requires prior knowledge of genes and transcripts. Aside from the whole-genome tiling arrays designed to interrogate an entire genome (Mockler et al., 2005), this technology does not allow the characterization of new transcriptional events and, ultimately, the discovery of new genes. Nonspecific hybridization can also result in biased transcript quantification (Pozhitkov et al., 2007). Even though the number of PubMed records using the term "microarray" is declining since 2015, most probably because of the democratization of high-throughput RNA-sequencing (RNA-seq), the overall fast assessment of gene expression at a reasonable price explains why microarrays remain a widely-used technology.

Over the last decade, ultra-high-throughput sequencing (UHTS) technologies have revolutionized transcriptomics (Morozova et al., 2009; Wang et al., 2009), and all fields under the umbrella of genomics. Briefly, total RNAs or a subset of these are reverse-transcribed, amplified by PCR and fragmented. Subsequently, millions of short DNA fragments are sequenced in parallel, leading to generation of many sequences called reads. The mapping of these reads onto a reference genome (genome-based assembly) or of reads to each other (de novo assembly) is then required to reconstruct the initial transcripts. Finally, the

15 expression level is assessed by counting reads associated to each transcript or gene (Figure 1). Such quantification methods have been shown to be accurate and well-correlated to other technologies such as microarrays, and to eventually outperform these in terms of accuracy for low-abundance transcripts (Chen et al., 2017a; Izadi et al., 2016; Wang et al., 2014). Since the emergence of RNA-seq, the accuracy and sensitivity of related methodologies have greatly improved. In addition, these techniques have diversified

20 to respond to scientists' specific biological questions (Head et al., 2014). For example, the sequencing depth can be improved by selecting RNAs of specific interest, such as polyA-RNAs, or by depleting undesired ones (e.g. rRNAs). Depending on the study's focus, the sequencing protocol can also be optimized. Single-end sequencing is usually sufficient for gene expression analysis, while paired-end sequencing is highly recommended for the purpose of transcript assembly - an absolute pre-requisite to the identification of new isoforms or novel genes (Conesa et al., 2016). Preserving strand information is also crucial to determine the direction in which a given locus is transcribed, allowing a better gene prediction in non-model organisms and the discovery of antisense lncRNAs. Over the past years, many bioinformatic tools have also been developed to improve all steps of UHTS analyses, including mapping of reads to a reference genome, transcript reconstruction and quantification, and differential expression analysis. Rather than describing the best practices in experimental design (Hardwick et al., 2017), RNA-seq protocol (Conesa et al., 2016; Han et al., 2015; Hrdlickova et al., 2017) or differential expression analysis (Fang et al., 2012; Huang et al., 2015; Kvam et al., 2012; Wu and Wu, 2016), this review intends to illustrate the wide range of biological questions that can be answered, thanks to these sequencing methods, using the testis as a complex organ model. 
The establishment and maintenance of testicular functions, i.e. the secretion of several hormones including androgens and the continuous production of male gametes, require a permanent communication network between several cell types. The testicular transcriptome therefore represents the sum of transcripts expressed in distinct cell populations, present in various proportions within the testis, including

5 Leydig cells (that produce androgens), peritubular cells (that surround seminiferous tubules), Sertoli cells (that support germ cells) and germ cells (GCs) at various differentiation stages (mitotic spermatogonia, meiotic spermatocytes and haploid spermatids). Despite its extreme cellular complexity, a commonly-used strategy to study the testis consists of using the whole organ at different ages: fetal or postnatal. The expression changes highlighted with such approaches can be used to identify: i) expression dynamics within a given cell population, and/or ii) preferential expression in cell types whose proportions fluctuate during development. Additionally, many techniques allow the isolation of enriched populations of each testicular cell type (Figure 2). These two different strategies have recently been combined with the UHTS methods, notably RNA-seq, to gain insights into testis biology.

\section{Tissue profiling analyses and first evidences of a testicular specificity}

RNA-seq has been used in a wide range of species to perform tissue profiling analyses, i.e. studies in which the transcriptomes of various tissues or organs, including the testis, are analyzed and compared. A pioneer study using RNA-seq was performed on several tissues in humans and rodents (Ramsköld et al., 2009). This study demonstrated that the most complex tissues in terms of number of expressed genes and RNA classes were the brain, kidney and testis. With the aim of describing the evolutionary dynamics of the mammalian transcriptomics, Brawand and colleagues investigated six organs from several species representing mammalian lineages and avians (Brawand et al., 2011). This analysis pointed towards the testis being the most rapidly evolving organ with regards to gene expression, thereby confirming previous phenotypic observations (Harcourt et al., 1981). UHTS has also been combined with proteomics analysis in order to define the specific proteome of several organs (Djureinovic et al., 2014). The authors used RNA-seq as a clue to determine the protein-coding genes specifically expressed in all the tissues analyzed and concluded that the testis was by far the organ with the highest number of tissue-specific genes. Additionally, a landmark RNA-seq study comparing transcriptomes of 24 tissues and cell types in Humans was performed to gain insight into the role of IncRNAs in testis specificity (Cabili et al., 2011). The authors found that lncRNAs are transcribed in a highly tissue-specific manner and that a third of these are predominantly expressed in the testis. These results were further confirmed by a tissue profiling analysis across 11 species, including mammals and tetrapods (Necsulea et al., 2014), which also showed that the high divergence rate of genes expressed within the testis does not exclusively apply to protein-coding 
genes, but is also inclusive of lncRNAs. This testis-specific expression of lncRNAs was further investigated by Zhang and collaborators, who performed RNA-seq on the whole testis and mature sperm. They compared their results with six other mouse tissues by integrating available data from NONCODE database, and they found that almost 7000 sequenced lncRNAs were exclusively expressed in the testis or sperm. Unlike other tissues, the average level of lncRNAs expression appeared higher than that of mRNAs in mature sperm.

These RNA-seq based studies have confirmed previous findings from microarray experiments (for reviews, see: Calvel et al., 2010; Chalmel and Rolland, 2015; Zhu et al., 2015) and have provided additional insight into testis-specificity of lncRNAs. The high tissue-specificity of the adult testis is mostly

10 due to the germline expression program. During differentiation (i.e. meiosis and spermiogenesis), male GCs undergo unique biological processes that require molecular factors expressed exclusively in the testis. Additionally, strong evolutionary constraints appear to act on the male gonad, shaping its genes with exaggerated traits, at both transcripts’ sequences and expression levels.

\section{Gonad development and somatic cell differentiation}

Following sexual differentiation, the bipotent gonad differentiates to either a testis or an ovary. In the testis, this involves the differentiation of Sertoli and Leydig cells, the formation of testis cords as well as the early establishment of a relatively prominent vasculature. These developmental processes occur during the entire embryonic period and continue after birth. Many microarray studies have investigated these critical processes in various species and paved the way for a better understanding of the underlying molecular mechanisms (Beverdam and Koopman, 2005; Bouma et al., 2007; Combes et al., 2011; del Valle et al., 2017; Houmard et al., 2009; Jameson et al., 2012; Munger et al., 2013; Small et al., 2005). To date, only a few studies performed in non-mammalian species, have analyzed this process at the whole organ level with the use of RNA-seq.

For instance, the transcriptomes of chicken ovaries and testes at two developmental time-points

25 surrounding sex differentiation (4.5 and $6 \mathrm{dpc}$ ) were investigated using a poly(A)-enrichment protocol (Ayers et al., 2015). Additionally, the transcriptional dynamics throughout gonadal development were studied in Portunus trituberculatus by sequencing whole testis and ovaries at various stages of development (Meng et al., 2015). The authors undertook de novo transcript assembly using the Trinity tool (O’Neil and Emrich, 2013) and used protein databases (Nr, Pfam, Swiss-Prot) as well as Blast2go and

30 WEGO softwares for annotation purposes. Owing to the non-reliance of RNA seq on genome annotation, it offered a great potential of discovery in non-model species studies. 
Till date, only a single study has focused on somatic cell differentiation within the fetal mammalian testis using RNA-seq (McClelland et al., 2015). The authors used FACS to isolate sf1-eGFP cells from mouse testes at different stages. By comparing Sertoli cells (high-GFP cells), Leydig cells (low-GFP cells) and GFP-negative cells, they were able to identify 61 genes, previously unknown to be involved in fetal Leydig cells differentiation, prior to the onset of steroidogenic genes. In this context, it is also worth mentioning the RNA-seq analysis of Sertoli cells isolated from Sox9-EGFP mouse testes at different postnatal ages (Zimmermann et al., 2015). This study also integrated data from purified GCs (Soumillon et al., 2013) to filter out transcripts arising from potential residual GCs. By doing so, the authors successfully described the expression dynamics of known transcripts as well as of newly discovered isoforms and unannotated transcripts (29 novel unknown intronic or intergenic transcripts) in Sertoli cells as they differentiate from immature proliferating cells to mature quiescent cells (in charge of sustaining spermatogenesis).

\section{Primordial germ cells and gonocytes}

Studies on sex differentiation and testicular somatic cells using RNA-seq are less numerous than 15 microarray-based studies (see above). However, there have been many studies investigating primordial germ cells (PGCs) and/or gonocytes by means of UHTS over the recent years. These cells indeed undergo a deep epigenetic reprograming involving removal of cytosine methylation from imprinted genes and restoration of totipotency (Hajkova et al., 2010; Popp et al., 2010; Seki et al., 2005) (reviewed in this issue). In this context, many studies have characterized the chromatin status of immature GCs from Oct4-

20 GFP mice (Hammoud et al., 2015; Kubo et al., 2015; Lesch et al., 2013; Seisenberger et al., 2012) by combining RNA-seq together with epigenomics technologies (for review, see : Mensaert et al., 2014), including bisulfite sequencing (BS-seq), (hydroxyl-)methylated DNA immunoprecipitation followed by sequencing ((h)MeDIP-seq) (Jacinto et al., 2008; Jin et al., 2011); chromatin immunoprecipitation followed by sequencing (ChIP-seq) (Park, 2009), or nucleosome occupancy and DNA methylation profiling followed by sequencing (NOMe-seq) (Kelly et al., 2012). A first study compared gene expression and DNA methylation (using BS-seq) and showed that global erasure of methylation does not lead to promiscuous transcription, including retrotransposons, suggestive of other transcriptional repression mechanisms in these cells (Seisenberger et al., 2012). A second study correlated transcriptional activity with poised chromatin domains, i.e. which harbor both activation (H3K4me3) and repression (H3K27me3) histone marks, using ChIP-seq and highlighted a set of essential developmental regulators which poised chromatin state was conserved from fetal life (in PGCs) to adulthood (in meiotic and postmeiotic germ cells) (Lesch et al., 2013). The authors further proposed that the flexible transcriptional state 
of these genes from fertilization onwards is essential to regenerate totipotent cells from differentiated germ cells. Finally, one study combined BS-seq and RNA-seq to compare mouse gonocytes (16.5dpc), prospermatogonia (0.5 dpp), undifferentiated (KIT-) and differentiating (KIT+) spermatogonia (7.5 dpp), allowing to correlate methylation status together with were changes in expression of important genes 5 (Kubo et al., 2015).

In humans, the in vitro differentiation of the PGC like cells (hPGCLCs) from embryonic stem cells (hESCs) could represent a great mean for the study of PGCs but such models also require a better understanding of fetal GCs. For instance, a first transcriptional landscape of purified gonocytes (cKIT+) from human fetal testes and ovaries, between 8 and 20 gestational weeks (GW), was generated to evaluate and compare five protocols for in vitro generation of hPGCLCs, all of which proved unsatisfactory (Gkountela et al., 2013). In 2015, four independent studies investigated human PGCs and gonocytes between 4 and 19 GW using similar isolation procedures (Gkountela et al., 2015; Guo et al., 2015; Irie et al., 2015; Tang et al., 2015). Combination of RNA-seq and BS-seq produced comprehensive datasets involving transcriptional and single-base-resolution methylome dynamics during GC development. Except

15 for SINE-variable number of tandem repeats-Alu elements (SVAs) (Tang et al., 2015), global DNA demethylation was not found to correlate with gene upregulation, notably for transposons, implicating the presence of another regulatory process (Gkountela et al., 2015; Tang et al., 2015). Another study combined RNA-seq and NOMe-seq with previously published ChIP-seq data (H. Guo et al., 2017), showing that that promoters' accessibility is strongly correlated to the corresponding gene expression

20 level. The SVAs elements also specifically displayed an open state in fetal GCs. In terms of transcriptional and epigenomic dynamics during GC development, two studies have successfully highlighted similarities as well as significant differences between human and mouse (H. Guo et al., 2017; Tang et al., 2015). Other labs also developed protocols for the in vitro differentiation of hPGCLCs from hESCs or human induced pluripotent stem cells (hISPCs). A first group evaluated such in vitro differentiation protocol by 25 comparing hPGCLCs to hPGCs, cultured hESCs, pre-induced cells, the seminoma-derived Tcam-2 cell line as well as somatic cells using RNA-seq (Irie et al., 2015). They first showed a significant correlation between the transcriptomes of hPGCLCs, hPGCs and Tcam-2 cells. They also identified hPGCLCs as potential “differentiating” hPGCs as they do not express the typical late germ cell markers DAZL, VASA and MAEL, further demonstrating that hPGCLCs constitute an interesting model to investigate the mechanisms of human germ line establishment. Most importantly, they identified the requirement of SOX17 for specification of human PGCs (Irie et al., 2015). A second group compared the transcriptome of hPGCLCs with other previously published RNA-seq data and evidenced significant differences in terms of gene expression program and epigenetic reprogramming between human and mouse PGCLCs as well as 
regarding the respective timing of specification and reprogramming between these species (von Meyenn et al., 2016).

\section{Spermatogonial stem cells}

Spermatogonia (Spg) constitute a heterogeneous population of male GCs that include spermatogonial stem cells (SSC), proliferative progenitor Spg and differentiating Spg committed to spermatogenesis. In mouse, undifferentiated Spg consist of type A single (As), paired (Apr) and aligned (Aal4-16) Spg while differentiating Spg consist of A1-4 Spg, intermediate Spg and type B Spg. Whether only As Spg encompass the pool of SSC is still a matter of debate (for review, see Lord and Oatley, 2017). In humans, there are only three types of Spg: undifferentiated Adark and Apale Spg, which are thought to be reserve and active SSC, respectively, and type B Spg which are differentiating progenitors (Boitani et al., 2016).

An extensive characterization (RNA-seq, smallRNA-seq, ChIP-seq and BS-Seq) of mouse GCs at different stages, including self-renewing Spg (THY1+), differentiating Spg (KIT+), spermatocytes (Spc), spermatids (Spt) and mature sperm allowed for the unraveling of key pathways regulating the balance between self-renewal and differentiation of SSCs (Hammoud et al., 2014). This study also showed

15 epigenetic specificities concerning these cells, which includes the poising of key transcription factors as well as the activity of DNA-methylated promoters during gametogenesis. By including additional markers (THY1, KIT, OCT4, ID4, and GFRa1), the same group further characterized the transcriptome and epigenome of adult mice SSCs (Hammoud et al., 2015) and proposed a classification of spermatogonial subpopulations, i.e. epithelial-like Spg (THY1+; highOCT4, ID4, and GFRa1), mesenchymal-like Spg

20 (THY1+; moderate OCT4 and ID4; high mesenchymal markers), and Spg committed to gametogenesis (high KIT+), that differ in terms of methylation status and imprinting. The recent identification of ID4 as being preferentially-expressed in a subset of mouse As Spg and playing an important role in the maintenance of SSC pool (Oatley et al., 2011), allowed further characterization of the SSC transcriptome (Chan et al., 2014; Helsel et al., 2017; Hermann et al., 2015; Mutoji et al., 2016). Taking advantage of

25 previously-published transcriptomic datasets (Hammoud et al., 2015; Mutoji et al., 2016), a list of 123 genes representing the core expression program of SSC was identified (Helsel et al., 2017).

A great work has been recently conducted, using SSEA4 as a marker of human SSCs, and KIT as a marker of Spg committed into gametogenesis (J. Guo et al., 2017). The authors performed whole-genome bisulfite sequencing (WGBS), Assay for Transposase-Accessible Chromatin with highthroughput sequencing (ATAC-seq) and RNA-seq on these two purified cell populations, aiming to describe the complete DNA methylation, chromatin and transcriptional states which may explain their stem-ness differences, and focused their analysis on pluripotency factors. Single-cell RNA-seq technologies were 9 
also used to profile the transition between SSEA4+ and KIT+ cells. The authors described four distinct cellular states, which highlight more precisely the differentiation pathway of human SSCs. This work represents a great example of the complementarity and power of different high-throughput technologies (J. Guo et al., 2017).

A number of studies have also been conducted in order to characterize the repertoire of ncRNAs, including sncRNAs, expressed in immature male GCs. The pioneer work in this field compared mouse SSC (THY1+) to somatic cells (THY1-) and identified a set of preferentially-expressed miRNAs in selfrenewing SSC (Niu et al., 2011). The use of unbiased sequencing also confirmed that piRNAs represent the preponderant class of smallRNA in differentiating mouse GCs, i.e. Spc and Spt, whereas, other cell types such as ESCs, SSCs, Sertoli cells, and mesenchymal stem cells preferentially express miRNAs (Tan et al., 2014). Recently, RNA-seq was also used to characterize not only classical mRNAs and lncRNAs but also circular RNAs (circRNAs) expressed in SSCs and ovarian germline stem cells (X. Li et al., 2017). circRNA is a novel class of ncRNA which specificity lies in its covalent bond linking the $3^{\prime}$ and $5^{\prime}$ ends generated by backsplicing (for review, see: Huang et al., 2017). Thanks to correlation analysis, a

15 competing endogenous RNA (ceRNAs) network, comprising lncRNA-miRNA-circRNA-mRNA, identified competitive RNAs - capable of binding and inhibiting the regulatory activities of other RNAs.

\section{Gene expression program at play during spermatogenesis}

While at the first glance, working with a whole organ might seem irrelevant for studying GC differentiation, it has been successfully demonstrated that in several mammalian species (including rodents), the first wave of spermatogenesis is synchronous in all seminiferous tubules (Bellvé et al., 1977; Oakberg, 1957, 1956). Therefore, following the evolution of the testicular transcriptome at representative post-natal ages allows extrapolation of the gene expression program of each GC population (Figure 2). This hypothesis is based on the assumption that observed transcriptional variations are due to germline differentiation. This strategy has the critical advantage of conserving the testis's integrity by preserving cell junctions and avoiding transcriptome modifications inherent to cell isolation procedures. In 2013, Gong and collaborators were among the first to profile the transcriptome of the developing mouse testis at three postnatal stages (infant, 6 dpp; juvenile, 4 weeks after birth; and, adult, 10 weeks after birth) using UHTS and a polyA-enrichment protocol (Gong et al., 2013). At the same time, Laiho and collaborators published about the transcriptome evolution during the first wave of spermatogenesis using postnatal mouse testes at 7, 14, 17, 21 and 28 dpp (Laiho et al., 2013). Instead of using a classical polyA-enriched approach, the authors used a rRNA depletion strategy to characterize the transcriptional dynamics of a 
wide range of protein-coding and noncoding transcripts. They observed for the first time that lncRNAs accumulate during meiotic and postmeiotic stages.

Kaessmann's lab was among the first to determine the cellular source of the testicular transcriptome complexity during mouse spermatogenesis (Soumillon et al., 2013) using RNA-seq on five enriched populations of testicular cells including Sertoli cells, type A Spg, pachytene Spc, round Spt and spermatozoa (Spz). Their results confirmed that meiotic and postmeiotic GCs have the highest transcriptome complexity (considering protein-coding genes, lncRNAs, pseudogenes or transposable elements), in comparison to testicular somatic cells (Sertoli cells) or other organs. At the same time, Gan and colleagues also published a landmark paper describing global 5-hydroxymethylcytosine distribution in GCs and its impact on the mouse germline transcriptional landscape (Gan et al., 2013). The authors sequenced the transcriptome of seven isolated cell populations (primitive SpgA, SpgA, SpgB, preleptotene Spc, pachytene Spc, round Spt and elongated Spt) and found that the highest transcriptional transitions during spermatogenesis occurred between preleptotene Spc and pachytene Spc, and also between pachytene Spc to round Spt. The following year, Chalmel and collaborators used RNA-seq to study the rat

15 testicular noncoding expression program and to discover novel genes (Chalmel et al., 2014). Four distinct testicular cell populations (Sertoli cells, Spg, Spc and Spt) were investigated using a rRNA depletion strategy. This allowed them to discover 1419 novel genes, called TUTs for testis-expressed unannotated transcripts, most of which exhibited characteristic genomic features of lncRNAs. This study confirmed that IncRNAs and TUTs accumulate in the meiotic and postmeiotic GCs (Laiho et al., 2013; Soumillon et

20 al., 2013) and identified a distinct class of meiosis-related lncRNAs exhibiting exons twice as long as those of other transcripts. By using a "proteomics informed by transcriptomics” (PIT) strategy combining RNA sequencing data with shotgun proteomics analyses, the authors further identified 44 novel proteincoding transcripts initially thought to be lncRNAs or TUTs (Chocu et al., 2014; Evans et al., 2012). Recently, Da Cruz and colleagues took advantage of improved FACS-based methods (da Cruz et al., 2016) to isolate leptotene/zygotene Spc, pachytene Spc, secondary Spc, and round Spt and subsequently performed RNA-seq analysis. Their meiosis-centric study revealed a large number of genes showing a burst of expression at the leptotene/zygotene stage. The authors also confirmed that the transcription of some spermiogenesis-related genes is initiated as early as pachytene Spc. They also found that some Xlinked genes are overexpressed during meiosis, thus escaping the meiotic sex chromosome inactivation (MSCI) (Ichijima et al., 2012; van der Heijden et al., 2011). Another RNA-seq study on five enriched mouse GCs populations focused on IncRNAs and also identified candidate genes that escape MSCI (Wichman et al., 2017). Moreover, another study analyzed the differential expression of not only mRNAs, lncRNAs but also included circRNAs in mouse primitive SpgA, preleptotene Spc, pachytene Spc and rSpt (Lin et al., 2016). Interestingly, the authors minimized the limitations of their study by taking advantage of 
several previous transcriptomic studies to define the set of testis-specific genes expressed in their samples (Brawand et al., 2011; Cabili et al., 2011), assess the conservation of the spermatogenic expressed lncRNAs (Necsulea et al., 2014), compare the circRNAs production across mouse tissues (Rybak-Wolf et al., 2015) and investigate the expression of potential precursors of piRNAs ( $\mathrm{Li}$ et al., 2013).

In humans, microarray experiments have been conducted to decipher the specific transcriptome of testicular cell populations and to identify key genes involved in spermatogenesis by using biopsies from patients with distinct infertility phenotypes (Chalmel et al., 2012; Ellis et al., 2007; Fox et al., 2003; Gatta et al., 2010; Nguyen et al., 2009; Okada et al., 2008; Spiess et al., 2007; von Kopylow et al., 2010). Similar approached were also used in rodents with GC-deficient models (Ellis et al., 2004), and chemical induced infertility (Orwig et al., 2008; Rockett et al., 2001). Recently, studies have relied on testicular samples from patients who underwent orchiectomy (Djureinovic et al., 2014). Zhu and colleagues used testicular biopsies of patients with obstructive azoospermia (i.e. with normal spermatogenesis) and combined FACS and MACS methods to obtain purified Spg, Spc and Spt (Zhu et al., 2016). The RNA-seq analysis allowed them to describe stage specific expression of known protein-coding and lncRNAs, as well as to focus their analysis on potential key transcriptional regulators of each GC stage such as HOXs, JUN, SP1, and TCF3. Recently, Jégou and collaborators published a RNA-seq analysis on five testicular cell populations including Leydig cells, Sertoli cells, peritubular cells, Spc and Spt (Jégou et al., 2017). By classifying differentially expressed genes into three broad co-expression clusters associated with somatic, meiotic or postmeiotic cells, the authors found that genes expressed during meiosis are significantly depleted in archaic hominin alleles (Sankararaman et al., 2016, 2014). Jan and collaborators used a microdissection approach to obtain enriched cell populations from adult human testis including $\mathrm{A}_{\text {dark }}$ and $\mathrm{A}_{\text {pale }}$ Spg, leptotene/zygotene Spc, early pachytene Spc, late pachytene Spc and round Spt (Jan et al., 2017). The dynamic changes of transcriptome have been characterized during human germline differentiation and enlightened that the Spg express transcripts, at protein level, which are required in later stages of spermatogenesis. The authors also compared their sequencing results with previously published datasets, in order to assess the efficiency of their cell isolation protocol (Zhu et al., 2016), and to define the conserved expression program between human ad mouse spermatogenesis in GCs populations (da Cruz et al., 2016).

\section{Splicing factors and regulatory RNA at play during male germ cell differentiation}

RNA-binding proteins and splicing factors play a critical role during male gamete development (for reviews, see Bettegowda and Wilkinson, 2010; Elliott, 2004; Idler and Yan, 2012; Paronetto and Sette, 2010; Venables, 2002; Walker et al., 1999). Several studies also took great advantage of RNA-sequencing 
to study splicing events occurring during spermatogenesis and particularly in the meiosis phase. Schmid and collaborators compared the transcriptome between whole mouse testis before GCs enter meiosis (6dpp) and at the end of the process (21dpp) (Schmid et al., 2013). They used a dedicated pipeline, MISO (Katz et al., 2010), to identify differentially regulated isoforms or exons across samples, revealing 5 switches in splicing patterns during the meiotic process. They pointed out several splicing factors that may play a key role in the evolution of meiotic protein isoforms, which can be possibly crucial for the germline mitotic-meiotic transition. Margolin and colleagues investigated whole testes at eight developmental stages of between 6 and 38 dpp (Margolin et al., 2014). They identified more than 13000 novel isoforms, including 159 predicted transcripts mapped in intergenic regions, further demonstrating that alternative spliced isoforms are abundant through spermatogenesis. They found transcripts mapping on unknown splice junctions for which an open reading frame was maintained. In 2016, the dynamics of the transcriptional landscape governing testis maturation (20 dpp, $75 \mathrm{dpp}, 270 \mathrm{dpp}$ ) has also been characterized in two closely related species, Meishan and Duroc boars (Ding et al., 2016). Using Sus scrofa as the reference genome to map reads, the authors enlightened a set of potential critical genes for

15 the onset of spermatogenesis. They used a dedicated strategy based on the SOAPsplice tool, allowing them to identify alternative splicing events (Huang et al., 2011). Importantly, transcriptomic differences in such closely related species illustrates the high divergence of transcription within the testis across mammalian species. Alternative splicing has also been explored in enriched mouse populations of Spc and Spt, to decipher more precisely the splicing changes occurring through transmeiotic differentiation of GC

20 (Naro et al., 2017). Following a polyA-enrichment protocol, the authors used the FAST-DB splicing annotation tool and identified intron retention (IRT) as being the most represented pattern. They showed that IRTs are highly stable transcripts that accumulate in the meiotic nuclei and are enriched in genes involved in mature gamete functions (i.e. Spt development and sperm-egg recognition). The authors therefore suggested that IRT allows storage and stabilization of key transcripts after the transcriptional burst in meiotic cells until their translation in transcriptionally-silenced post-meiotic cells.

Besides the widely described mRNAs and lncRNAs, sncRNAs are involved in many expression regulation pathways and can be divided in different classes according to their genomic features and sequence modifications. Specific RNA-seq protocols had to be developed to allow smallRNA purification, library preparation and sequencing, as well as mapping and annotation of corresponding reads. The role of sncRNAs in testis maturation and spermatogenesis have been recently reviewed (for reviews, see Luo et al., 2016; Meikar et al., 2011; Yadav and Kotaja, 2014), and will not be extensively described here. Briefly, sncRNA profiling and differential expression analyses were performed on testes at different developmental stages (Gebert et al., 2015; Li et al., 2016; Lian et al., 2012; Liu et al., 2012), by comparing the testis with other tissues (Luo et al., 2015), including the ovary (Kowalczykiewicz et al., 2014; Li et al., 13 
2011). Several works used whole mouse testes at different ages to study the specific biogenesis of piRNAs during spermatogenesis (Beyret et al., 2012; Li et al., 2013). In humans, the small noncoding transcriptome has also been characterized in the adult testis (Ha et al., 2014; Yang et al., 2013) and several other studies have been performed on purified GCs to understand the implication of such sncRNAs during spermatogenesis (Gan et al., 2011; García-López et al., 2015; Goh et al., 2015; Vourekas et al., 2012; Zhang et al., 2015).

The Noora Kotaya's laboratory is particularly known in the field of reproductive biology for its work on the chromatoid body (CB). The CB is a GC-specific organelle composed of RNAs and RNA-binding proteins which appears in the cytoplasm of GCs during the transition between meiotic and post-meiotic phase of spermatogenesis (Kotaja and Sassone-Corsi, 2007; Meikar et al., 2011; Parvinen, 2005; Peruquetti, 2015). Meikar and collaborators isolated CBs from juvenile mouse testes at 22 and 26 dpp using several steps of cell lysis, filtration and immunoprecipitation (Meikar et al., 2014). They combined sncRNA-seq and RNA-seq to compare purified CB to round Spt and identified sncRNAs, lncRNAs and mRNAs that accumulate within this organelle. This analysis showed that lncRNAs identified as genomic

15 clusters generating piRNAs, accumulate in the CB, suggesting their important role in piRNAs biogenesis. However, a proteomic analysis failed at identifying the core primary piRNA processing components within the $\mathrm{CB}$, therefore challenging the role of this organelle in the biogenesis of piRNAs.

\section{Resources}

While microarrays remain useful and accurate tools for measuring expression levels, RNA-seq 20 provides a more complete transcriptomic solution by allowing transcript isoform determination and eventually new gene discovery, on top of being more accurate when it comes to quantification (Chen et al., 2017b; Izadi et al., 2016; Malone and Oliver, 2011; Wang et al., 2014). With the continuous decrease of sequencing costs, the number of RNA-seq studies therefore drastically increased over recent years, and the corresponding datasets now present a great potential for reanalysis or integration within one's own study. Similar to microarrays, the MIAME compliance (Brazma et al., 2001) applies to UHTS data and generalist databases such as the Gene Expression Omnibus (GEO, http://www.ncbi.nlm.nih.gov/geo/) (Barrett et al., 2012), or the ArrayExpress (Kolesnikov et al., 2015, https://www.ebi.ac.uk/arrayexpress/) resources, also serve as repositories of high-throughput sequencing data. Most of the datasets arising from studies described in this review are therefore publicly available in these public repositories (see Supplemental Table). Despite that several groups have already taken advantage of these available resources, differences in sequencing protocols, such as transcript type and size selection, strand- 
specificity, length or pairing of reads, may somehow prevent full integration of, or direct comparison between different datasets.

Despite the wide use of UHTS, the handling of such data requires specific skills and is both time and resource consuming. Dedicated databases have therefore started to emerge in order to extract, summarize and/or visualize the corresponding information, including the field of reproductive biology. For instance, the ReproGenomics Viewer (RGV) is a useful toolbox dedicated to genomic data for the reproductive science community (Darde et al., 2015). It consists of a genome browser that allows the visualization of selected datasets from the literature in the genomic context of their respective species. Moreover, crossspecies comparisons are now possible, allowing simultaneous visualization of several types of data (e.g. RNA-seq, ChIP-seq) performed in different species. Currently, studies implemented in RGV mainly focus on testis biology and spermatogenesis, but this tool is likely to be regularly updated in order to expand its focus to other areas of reproductive biology. As described earlier in this review, lncRNAs are expressed in a highly tissue-specific manner and especially in male GCs. GermlncRNA constitutes a dedicated catalogue of known and novel lncRNAs (Luk et al., 2015), by integrating several published transcriptomic

15 studies covering three GC populations, i.e. type A Spg, pachytene Spc and round Spt (Gan et al., 2013; Lee et al., 2012, 2009; Soumillon et al., 2013; Sun et al., 2013). Last but not the least, Spermbase represents a great resource dedicated to sperm transcriptome in four mammalians species, i.e. human, rat, mouse and rabbit (Schuster et al., 2016). Using a standardized sperm RNA isolation and sequencing protocol, this work allows a comparative RNA-seq analysis, covering long as well as small RNAs, and identifying the conserved counterpart of the sperm transcriptome across mammalian species.

\section{New technologies and perspectives}

The application fields of UHTS technologies have expanded at an amazing pace since its emergence, enabling investigation of RNA as well as DNA, both quantitatively and qualitatively, at the sequence, structural, and conformation levels. In parallel, the accuracy and throughput of sequencing methods are also improving to overcome technical limitations. For instance, most current UHTS approaches involve amplification steps by PCR and rely on the sequencing of relatively short sequences in order to maintain reasonable sequencing error rates. The future of UHTS particularly relies on the use of PCR-free protocols, to prevent amplification biases, and on increasing the length of reads, to avoid or, at least, reduce and make easier assembly steps for both transcripts and chromosomes/genomes (Chu et al., 2017). In this context, it is worth mentioning the emergence of third generation sequencing technologies which allow the PCR-free or even the direct sequencing of single RNA molecules and generate long reads of up to several kilobases (Garalde et al., 2018; Laver et al., 2015; Lu et al., 2016; Rhoads and Au, 2015) 
(Figure 1). Such technologies remain very expensive and the sequence error rates are still very high (up to $10 \%$ ), but they are likely to improve on both aspects in the near future. Very importantly, and also quite unexpectedly, both technologies are able to capture information on bases' modifications such as methylation during the sequencing process.

The outcome of transcriptomic studies also greatly depends on the biological material. While whole organs preserve cell-cell interactions and reduce gene expression alterations due to extensive sample handling, they prevent access to discrete cell populations as well as to low-copy transcripts, and they do not allow to ascertain their cellular origins. On the other hand, cell enrichment protocols provide cell-type information and improve sensitivity, but potential contaminations and/or changes in expression cannot be ruled out. Moreover, such a bulk approach, even with enriched cell populations, is likely to mask differences between distinct subpopulations. Over the past years, single cell approaches have been developed and adapted to RNA sequencing (Figures 1 and 2). Single-cell RNA-seq (scRNA-seq) includes cell isolation and library preparation with molecular barcodes. Thanks to microfluidic (Klein et al., 2015; Zilionis et al., 2016), droplet-based (Macosko et al., 2015) or FACS-based methods (Jaitin et al., 2014),

15 scRNA-seq is able to capture the transcriptome of a very large number of cells. These high-throughput technologies (Ziegenhain et al., 2017) have proved very efficient for inferring and describing the temporal dynamic of cell differentiation, or the spatial description of different cell populations within an organ (Kalisky et al., 2017; Macaulay et al., 2017; Tanay and Regev, 2017; Wagner et al., 2016). In the field of reproductive biology, several single-cell transcriptomic studies have already been performed, on human PGCs/gonocytes and fetal somatic cells (Guo et al., 2015; L. Li et al., 2017) as well as on mouse fetal somatic cells (Stévant et al., 2018) (reviewed in this issue). scRNAseq is a promising technology that represents a great potential of discovery, but as with all other technologies, some experimental limitations are still in place. For instance, the dissociation of complex tissues into single-cell suspension can be the first limiting step. Single nucleus RNAseq (snuc-RNAseq) has initially been developed to overcome this issue in the brain (Habib et al., 2016; Lake et al., 2016), and then combined with microfluidic technology, leading to DroNc-seq (Habib et al., 2017). Furthermore, the different available technologies still show relatively low sensitivity, allowing to detect medium to highly expressed transcripts exclusively. Therefore, for now at least, these methods cannot replace classical RNA-seq approaches in terms of quantification accuracy and completeness.

The future of these single cell high-throughput technologies is evolving (Yuan et al., 2017), and many perspectives remain to be explored, such as in situ transcriptomic analysis (Coskun and Cai, 2016; Satija et al., 2015), live imaging transcriptomic analysis (Skylaki et al., 2016), lineage tracing (McKenna 
et al., 2016; Perli et al., 2016; Schmidt et al., 2017) or single-cell multi-omics (Cheow et al., 2016; Genshaft et al., 2016; Hou et al., 2016).

\section{Acknowledgements}

5 We thank Dr. Julien Dagher and Dr. Sadia Khan for critical reading of the manuscript. We also thank the Research Institute for Environmental and Occupational Health (Irset), the National Institute of Health and Medical Research (Inserm), the University of Rennes 1 and the French School of Public Health (EHESP) for supporting this work.

10 Funding: This work was supported by the French National Institute of Health and Medical Research (Inserm), the University of Rennes 1 and the French School of Public Health (EHESP). 


\section{Figures and Legends}

(a) Short-read sequencing

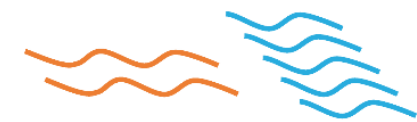

1) Poly-A selection

or rRNA depletion

2) Fragmentation, RT,

adapter ligation and PCR

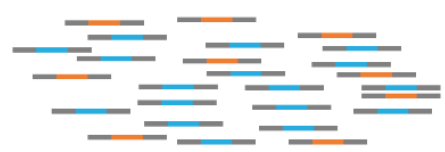

3) single- or paired-

read sequencing

4) Read mapping

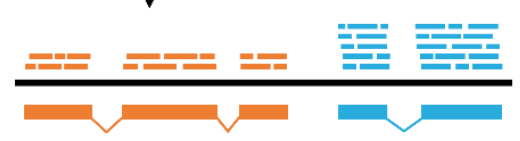

5) Transcript reconstruction and/or quantification (b) Digital gene expression
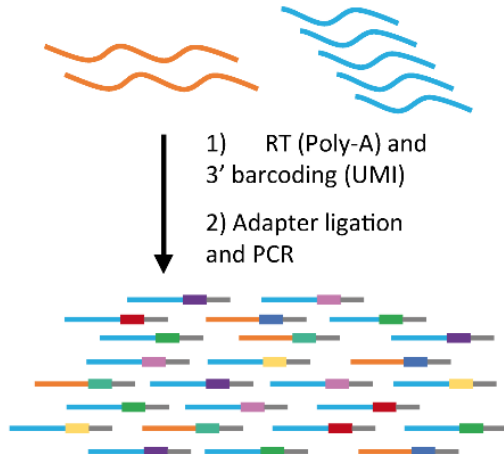

3) Sequencing, read mapping and UMI count

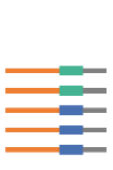

mRNA\#1 $=2$ UMIs

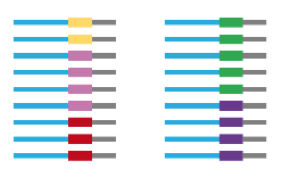

mRNA \#2 $=5 \mathrm{UMIS}$ (c) Long-read sequencing
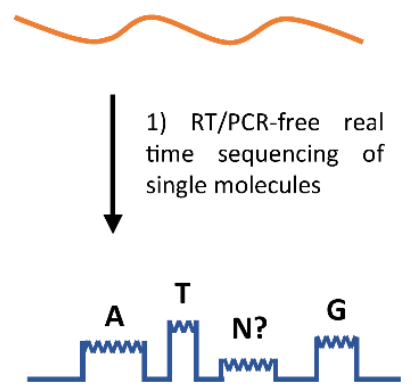

2) Error correction using consensus sequence

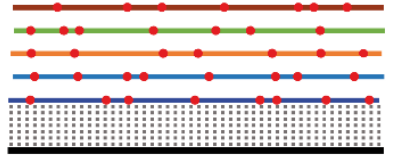

Figure 1. High-throughput sequencing technologies supporting transcriptomic analyses (2-column fitting, colors should be used).

5 (a) Until recently, most sequencing technologies have relied on the generation of relatively short reads (i.e. sequences of few tens to hundreds of nucleotides in length). When applied to the sequencing of RNA, following reverse transcription (RT) of either poly-A enriched or of ribosomal RNA (rRNA)-depleted transcripts, the bioinformatic analysis then consists in mapping reads to a reference sequence (typically the genome if available) prior to transcript assembly (based on reads spanning exonic junctions) and/or quantification (based on density of reads mapping each individual transcript/gene). (b) Alternatively, modified library construction protocols involve the barcoding of each cDNA by a Unique Molecular Index (UMI) during reverse transcription, followed by sequencing of the 3' extremity of the resulting cDNA. The counting of UMIs, rather than measuring read density, then allows more precise quantification, by correcting for eventual PCR biases. Such protocols were designed for differential gene expression analysis and are particularly well-suited for single-cell RNA-seq analyses as well as low-input samples. (c) Currently, third-generation sequencing technologies are revolutionizing many fields of genomics, including transcriptomics. These emerging technologies indeed differ from previous one since they allow the direct sequencing of RNAs (i.e. with neither reverse transcription nor PCR amplification) and the generation of long-reads (i.e. sequences of several tens of kilobases in length). Consequently, they make it 
possible to sequence full length transcripts, therefore avoiding the tedious and equivocal step of transcript assembly. The relatively low throughput (in terms of number of sequences delivered per run) at a still relatively high cost, however, do not make yet such technologies an appropriate solution for quantification purposes.

(a) First wave of spermatogenesis
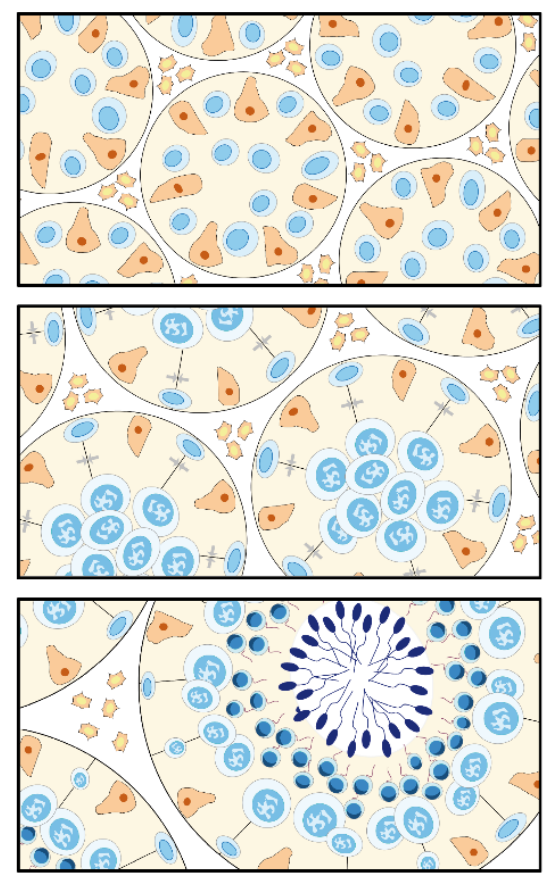

Pros: Limited sample handling and few resulting artifactual changes in expression

Cons: Dilution effects, limited detection of low abundance transcripts and rare cell populations (b) Spermatogenetic arrest, Cell depletion
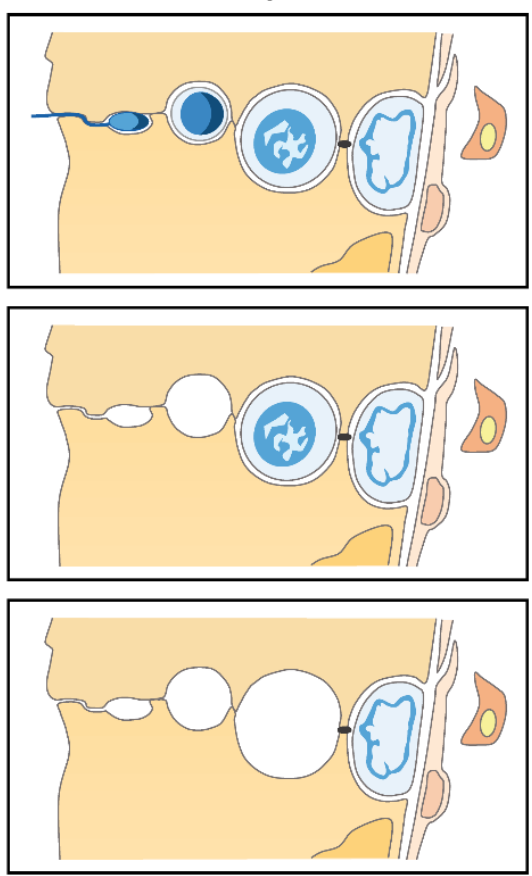

Pros: Limited sample handling and few resulting artifactual changes in expression

Cons: Dilution effects, limited detection of low abundance transcripts and rare cell populations, pathological tissues (c) Cell population purification

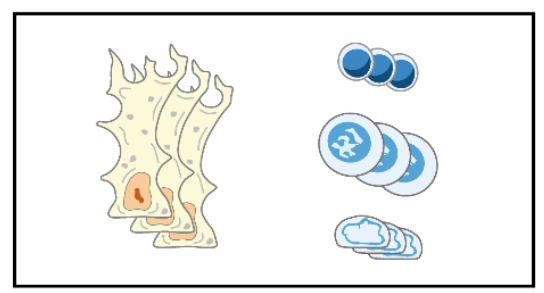

Pros: No dilution effects, access to low abundance transcripts and rare cell populations

Cons: Cell contaminants, changes in expression during sample handling

(d) Single cell capture

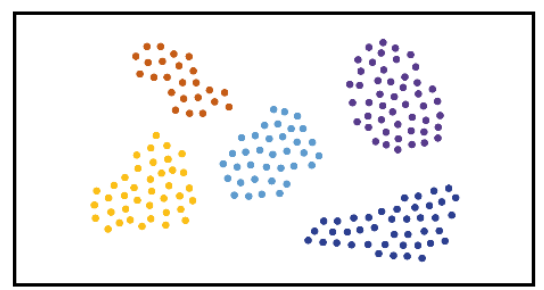

Pros: No dilution effects, virtual access to all cell populations

Cons: changes in expression during sample handling, low detection sensitivity, doublets/multiplets

Figure 2. Strategies to study gene expression during testis development and functions (2-column fitting, colors should be used).

Several strategies are typically used to investigate the transcriptomic profiles of testicular cells, notably during germ cell development. (a) These include the use of whole testes at various developmental stages during the first wave of spermatogenesis in various species. In such approaches, the specific or preferential expression program of a given cell type is inferred from the changes in expression observed between two stages during which this cell type appears. (b) Based on the same rationale, the use of testicular biopsies from patients with spermatogenesis arrested at distinct developmental stages has been commonly used in humans. (c) Alternatively, many isolation procedures enable to obtain enriched cell 
populations in order to investigate more directly the transcript content of various cell types present within the testis. (d) Finally, the relatively recent development of single-cell approaches combined with highthroughput technologies holds great promises for capturing and studying any cell type within a sample, including rare cell populations or cell subtypes for which absence of appropriate markers prevents 5 purification. Main advantages (Pros) and disadvantages (Cons) are indicated for each strategy. 


\section{References}

Ayers, K.L., Lambeth, L.S., Davidson, N.M., Sinclair, A.H., Oshlack, A., Smith, C.A., 2015. Identification of candidate gonadal sex differentiation genes in the chicken embryo using RNA-seq. BMC Genomics 16, 704. doi:10.1186/s12864-015-1886-5

Barrett, T., Wilhite, S.E., Ledoux, P., Evangelista, C., Kim, I.F., Tomashevsky, M., Marshall, K.A., Phillippy, K.H., Sherman, P.M., Holko, M., Yefanov, A., Lee, H., Zhang, N., Robertson, C.L., Serova, N., Davis, S., Soboleva, A., 2012. NCBI GEO: archive for functional genomics data setsupdate. Nucleic Acids Res. 41, D991-D995. doi:10.1093/nar/gks1193

Bellvé, A.R., Cavicchia, J.C., Millette, C.F., O’Brien, D.A., Bhatnagar, Y.M., Dym, M., 1977. Spermatogenic cells of the prepuberal mouse. Isolation and morphological characterization. J. Cell Biol. 74, 68-85.

Bettegowda, A., Wilkinson, M.F., 2010. Transcription and post-transcriptional regulation of spermatogenesis. Philos. Trans. R. Soc. Lond. B. Biol. Sci. 365, 1637-51. doi:10.1098/rstb.2009.0196

Beverdam, A., Koopman, P., 2005. Expression profiling of purified mouse gonadal somatic cells during the critical time window of sex determination reveals novel candidate genes for human sexual dysgenesis syndromes. Hum. Mol. Genet. 15, 417-431. doi:10.1093/hmg/ddi463

Beyret, E., Liu, N., Lin, H., 2012. piRNA biogenesis during adult spermatogenesis in mice is independent of the ping-pong mechanism. Cell Res. 22, 1429-1439. doi:10.1038/cr.2012.120

Boitani, C., Persio, S. Di, Esposito, V., Vicini, E., 2016. Spermatogonial cells: mouse, monkey and man comparison. Semin. Cell Dev. Biol. 59, 79-88. doi:10.1016/j.semcdb.2016.03.002

Bouma, G.J., Affourtit, J., Bult, C.J., Eicher, E.M., 2007. Transcriptional profile of mouse pre-granulosa and Sertoli cells isolated from early-differentiated fetal gonads, Gene Expression Patterns. doi:10.1016/j.modgep.2006.05.011

Brawand, D., Soumillon, M., Necsulea, A., Julien, P., Csárdi, G., Harrigan, P., Weier, M., Liechti, A., Aximu-Petri, A., Kircher, M., Albert, F.W., Zeller, U., Khaitovich, P., Grützner, F., Bergmann, S., Nielsen, R., Pääbo, S., Kaessmann, H., 2011. The evolution of gene expression levels in mammalian organs. Nature 478. doi:10.1038/nature10532

Brazma, A., Hingamp, P., Quackenbush, J., Sherlock, G., Spellman, P., Stoeckert, C., Aach, J., Ansorge, W., Ball, C.A., Causton, H.C., Gaasterland, T., Glenisson, P., Holstege, F.C.P., Kim, I.F., Markowitz, V., Matese, J.C., Parkinson, H., Robinson, A., Sarkans, U., Schulze-Kremer, S., Stewart, J., Taylor, R., Vilo, J., Vingron, M., 2001. Minimum information about a microarray experiment (MIAME)-toward standards for microarray data. Nat. Genet. 29, 365-371. doi:10.1038/ng1201-365

Cabili, M.N., Trapnell, C., Goff, L., Koziol, M., Tazon-Vega, B., Regev, A., Rinn, J.L., 2011. Integrative annotation of human large intergenic noncoding RNAs reveals global properties and specific subclasses. Genes Dev. 25, 1915-27. doi:10.1101/gad.17446611

Calvel, P., Rolland, A.D., Jégou, B., Pineau, C., 2010. Testicular postgenomics: targeting the regulation of spermatogenesis. Philos. Trans. R. Soc. Lond. B. Biol. Sci. 365, 1481-500. doi:10.1098/rstb.2009.0294

Cech, T.R., Steitz, J.A., 2014. The noncoding RNA revolution - Trashing old rules to forge new ones. Cell 157, 77-94. doi:10.1016/j.cell.2014.03.008

Chalmel, F., Lardenois, A., Evrard, B., Mathieu, R., Feig, C., Demougin, P., Gattiker, A., Schulze, W., Jégou, B., Kirchhoff, C., Primig, M., 2012. Global human tissue profiling and protein network analysis reveals distinct levels of transcriptional germline-specificity and identifies target genes for male infertility. Hum. Reprod. 27, 3233-48. doi:10.1093/humrep/des301

Chalmel, F., Lardenois, a., Evrard, B., Rolland, a. D., Sallou, O., Dumargne, M.-C., Coiffec, I., Collin, O., Primig, M., Jegou, B., 2014. High-Resolution Profiling of Novel Transcribed Regions During Rat Spermatogenesis. Biol. Reprod. 91, 5-5. doi:10.1095/biolreprod.114.118166

Chalmel, F., Rolland, A.D., 2015. Linking transcriptomics and proteomics in spermatogenesis. Reproduction 150, R149-57. doi:10.1530/REP-15-0073

Chan, F., Oatley, M.J., Kaucher, A. V, Yang, Q.-E., Bieberich, C.J., Shashikant, C.S., Oatley, J.M., 2014. 
Functional and molecular features of the Id4+ germline stem cell population in mouse testes. Genes Dev. 28, 1351-62. doi:10.1101/gad.240465.114

Chen, L., Sun, F., Yang, X., Jin, Y., Shi, M., Wang, L., Shi, Y., Zhan, C., Wang, Q., 2017a. Correlation between RNA-Seq and microarrays results using TCGA data. Gene 628, 200-204. doi:10.1016/j.gene.2017.07.056

Chen, L., Sun, F., Yang, X., Jin, Y., Shi, M., Wang, L., Shi, Y., Zhan, C., Wang, Q., 2017b. Correlation between RNA-Seq and microarrays results using TCGA data. doi:10.1016/j.gene.2017.07.056

Cheow, L.F., Courtois, E.T., Tan, Y., Viswanathan, R., Xing, Q., Tan, R.Z., Tan, D.S.W., Robson, P., Loh, Y.-H., Quake, S.R., Burkholder, W.F., 2016. Single-cell multimodal profiling reveals cellular epigenetic heterogeneity. Nat. Methods 13, 833-836. doi:10.1038/nmeth.3961

Chocu, S., Evrard, B., Lavigne, R., Rolland, a. D., Aubry, F., Jegou, B., Chalmel, F., Pineau, C., 2014. Forty-Four Novel Protein-Coding Loci Discovered Using a Proteomics Informed by Transcriptomics (PIT) Approach in Rat Male Germ Cells. Biol. Reprod. 91, 123-123. doi:10.1095/biolreprod.114.122416

Chu, J., Mohamadi, H., Warren, R.L., Yang, C., Birol, I., 2017. Innovations and challenges in detecting long read overlaps: an evaluation of the state-of-the-art. Bioinformatics 33, 1261-1270. doi:10.1093/bioinformatics/btw811

Combes, A.N., Bowles, J., Feng, C.-W., Chiu, H.S., Khoo, P.-L., Jackson, A., Little, M.H., Tam, P.P.L., Koopman, P., 2011. Expression and Functional Analysis of Dkk1 during Early Gonadal Development. Sex Dev 5, 124-130. doi:10.1159/000327709

Conesa, A., Madrigal, P., Tarazona, S., Gomez-Cabrero, D., Cervera, A., McPherson, A., Szcześniak, M.W., Gaffney, D.J., Elo, L.L., Zhang, X., Mortazavi, A., 2016. A survey of best practices for RNAseq data analysis. Genome Biol. 17, 13. doi:10.1186/s13059-016-0881-8

Coskun, A.F., Cai, L., 2016. Dense transcript profiling in single cells by image correlation decoding. Nat. Methods 13, 657-660. doi:10.1038/nmeth.3895

da Cruz, I., Rodríguez-Casuriaga, R., Santiñaque, F.F., Farías, J., Curti, G., Capoano, C.A., Folle, G.A., Benavente, R., Sotelo-Silveira, J.R., Geisinger, A., 2016. Transcriptome analysis of highly purified mouse spermatogenic cell populations: gene expression signatures switch from meiotic-to postmeiotic-related processes at pachytene stage. BMC Genomics 17, 294. doi:10.1186/s12864-0162618-1

Darde, T.A., Sallou, O., Becker, E., Evrard, B., Monjeaud, C., Le Bras, Y., Jégou, B., Collin, O., Rolland, A.D., Chalmel, F., 2015. The ReproGenomics Viewer: an integrative cross-species toolbox for the reproductive science community. Nucleic Acids Res. 43, W109-16. doi:10.1093/nar/gkv345

del Valle, I., Buonocore, F., Duncan, A.J., Lin, L., Barenco, M., Parnaik, R., Shah, S., Hubank, M., Gerrelli, D., Achermann, J.C., 2017. A genomic atlas of human adrenal and gonad development. Wellcome Open Res. 2, 25. doi:10.12688/wellcomeopenres.11253.1

Ding, H., Luo, Y., Liu, M., Huang, J., Xu, D., 2016. Histological and transcriptome analyses of testes from Duroc and Meishan boars. Nat. Publ. Gr. doi:10.1038/srep20758

Djureinovic, D., Fagerberg, L., Danielsson, A., Lindskog, C., 2014. The human testis specific proteome defined by transcriptomics and 20, 1-39. doi:10.1093/molehr/gau018

Elliott, D.J., 2004. The role of potential splicing factors including RBMY, RBMX, hnRNPG-T and STAR proteins in spermatogenesis. Int. J. Androl. 27, 328-34. doi:10.1111/j.1365-2605.2004.00496.X

Ellis, P.J.I., Furlong, R.A., Conner, S.J., Kirkman-Brown, J., Afnan, M., Barratt, C., Griffin, D.K., Affara, N.A., 2007. Coordinated transcriptional regulation patterns associated with infertility phenotypes in men. J. Med. Genet. 44, 498-508. doi:10.1136/jmg.2007.049650

Ellis, P.J.I., Furlong, R.A., Wilson, A., Morris, S., Carter, D., Oliver, G., Print, C., Burgoyne, P.S., Loveland, K.L., Affara, N.A., 2004. Modulation of the mouse testis transcriptome during postnatal development and in selected models of male infertility. Mol. Hum. Reprod. 10, 271-281. doi:10.1093/molehr/gah043

Evans, V.C., Barker, G., Heesom, K.J., Fan, J., Bessant, C., Matthews, D.A., 2012. De novo derivation of proteomes from transcriptomes for transcript and protein identification. Nat. Methods 9, 1207-11. 
doi:10.1038/nmeth.2227

Fang, Z., Martin, J., Wang, Z., 2012. Statistical methods for identifying differentially expressed genes in RNA-Seq experiments. Cell Biosci. 2, 26. doi:10.1186/2045-3701-2-26

Fox, M.S., Ares, V.X., Turek, P.J., Haqq, C., Reijo Pera, R.A., 2003. Feasibility of global gene expression analysis in testicular biopsies from infertile men. Mol. Reprod. Dev. 66, 403-421. doi:10.1002/mrd.10364

Gan, H., Lin, X., Zhang, Z., Zhang, W., Liao, S., Wang, L., Han, C., 2011. piRNA profiling during specific stages of mouse spermatogenesis. Bioinformatics. doi:10.1261/rna.2648411

Gan, H., Wen, L., Liao, S., Lin, X., Ma, T., Liu, J., Song, C.-X., Wang, M., He, C., Han, C., Tang, F., 2013. Dynamics of 5-hydroxymethylcytosine during mouse spermatogenesis. Nat. Commun. 4. doi:10.1038/ncomms2995

Garalde, D.R., Snell, E.A., Jachimowicz, D., Sipos, B., Lloyd, J.H., Bruce, M., Pantic, N., Admassu, T., James, P., Warland, A., Jordan, M., Ciccone, J., Serra, S., Keenan, J., Martin, S., McNeill, L., Wallace, E.J., Jayasinghe, L., Wright, C., Blasco, J., Young, S., Brocklebank, D., Juul, S., Clarke, J., Heron, A.J., Turner, D.J., 2018. Highly parallel direct RNA sequencing on an array of nanopores. Nat. Methods. doi:10.1038/nmeth.4577

García-López, J., Alonso, L., Cárdenas, D.B., Artaza-Alvarez, H., Hourcade, J. de D., Martínez, S., Brieño-Enríquez, M.A., Del Mazo, J., 2015. Diversity and functional convergence of small noncoding RNAs in male germ cell differentiation and fertilization. RNA 21, 946-62. doi:10.1261/rna.048215.114

Gatta, V., Raicu, F., Ferlin, A., Antonucci, I., Scioletti, A., Garolla, A., Palka, G., Foresta, C., Stuppia, L., 2010. Testis transcriptome analysis in male infertility: new insight on the pathogenesis of oligoazoospermia in cases with and without AZFc microdeletion. BMC Genomics 11, 401. doi:10.1186/1471-2164-11-401

25 Gebert, D., Ketting, R.F., Zischler, H., Rosenkranz, D., 2015. piRNAs from Pig Testis Provide Evidence for a Conserved Role of the Piwi Pathway in Post-Transcriptional Gene Regulation in Mammals. PLoS One 10, e0124860. doi:10.1371/journal.pone.0124860

Genshaft, A.S., Li, S., Gallant, C.J., Darmanis, S., Prakadan, S.M., Ziegler, C.G.K., Lundberg, M., Fredriksson, S., Hong, J., Regev, A., Livak, K.J., Landegren, U., Shalek, A.K., 2016. Multiplexed, targeted profiling of single-cell proteomes and transcriptomes in a single reaction. Genome Biol. 17, 188. doi:10.1186/s13059-016-1045-6

Gkountela, S., Li, Z., Vincent, J.J., Zhang, K.X., Chen, A., Pellegrini, M., Clark, A.T., 2013. The ontogeny of cKIT+ human primordial germ cells proves to be a resource for human germ line reprogramming, imprint erasure and in vitro differentiation. Nat. Cell Biol. 15, 113-22. doi:10.1038/ncb2638

Gkountela, S., Zhang, K.X.X., Shafiq, T.A.A., Liao, W.-W.W., Hargan-Calvopiña, J., Chen, P.-Y.Y., Clark, A.T.T., Hargan-Calvopi??a, J., Chen, P.-Y.Y., Clark, A.T.T., 2015. DNA demethylation dynamics in the human prenatal germline. Cell 161, 1425-1436. doi:10.1016/j.cell.2015.05.012

Goh, W.S.S., Falciatori, I., Tam, O.H., Burgess, R., Meikar, O., Kotaja, N., Hammell, M., Hannon, G.J., 2015. piRNA-directed cleavage of meiotic transcripts regulates spermatogenesis. Genes Dev. 29, 1032-44. doi:10.1101/gad.260455.115

Gong, W., Linlin, P., Qiang, L., Yuanyuan, Z., Chengqi, X., Xiaomin, Y., Peng, C., Songnian, H., Jun, Y., 2013. Transcriptome profiling of the developing postnatal mouse testis using next-generation sequencing 56, 1-12. doi:10.1007/s11427-012-4411-y

Guo, F., Yan, L., Guo, H., Li, L., Hu, B., Zhao, Y., Yong, J., Hu, Y., Wang, X., Wei, Y., Wang, W., Li, R., Yan, J., Zhi, X., Zhang, Y., Jin, H., Zhang, W., Hou, Y., Zhu, P., Li, J., Zhang, L., Liu, S., Ren, Y., Zhu, X., Wen, L., Gao, Y.Q., Tang, F., Qiao, J., 2015. The transcriptome and DNA methylome landscapes of human primordial germ cells. Cell 161, 1437-1452. doi:10.1016/j.cell.2015.05.015

Guo, H., Hu, B., Yan, L., Yong, J., Wu, Y., Gao, Y., Guo, F., Hou, Y., Fan, X., Dong, J., Wang, X., Zhu, X., Yan, J., Wei, Y., Jin, H., Zhang, W., Wen, L., Tang, F., Qiao, J., 2017. DNA methylation and chromatin accessibility profiling of mouse and human fetal germ cells. Cell Res. 27, 165-183. 
doi:10.1038/cr.2016.128

Guo, J., Grow, E.J., Yi, C., Mlcochova, H., Maher, G.J., Lindskog, C., Murphy, P.J., Wike, C.L., Carrell, D.T., Goriely, A., Hotaling, J.M., Cairns, B.R., 2017. Chromatin and Single-Cell RNA-Seq Profiling Reveal Dynamic Signaling and Metabolic Transitions during Human Spermatogonial Stem Cell Development. Cell Stem Cell 21, 533-546.e6. doi:10.1016/j.stem.2017.09.003

Ha, H., Song, J., Wang, S., Kapusta, A., Feschotte, C., Chen, K.C., Xing, J., 2014. A comprehensive analysis of piRNAs from adult human testis and their relationship with genes and mobile elements. BMC Genomics. doi:10.1186/1471-2164-15-545

Habib, N., Avraham-Davidi, I., Basu, A., Burks, T., Shekhar, K., Hofree, M., Choudhury, S.R., Aguet, F., Gelfand, E., Ardlie, K., Weitz, D.A., Rozenblatt-Rosen, O., Zhang, F., Regev, A., 2017. Massively parallel single-nucleus RNA-seq with DroNc-seq. Nat. Methods 14, 955-958. doi:10.1038/nmeth.4407

Habib, N., Li, Y., Heidenreich, M., Swiech, L., Avraham-Davidi, I., Trombetta, J.J., Hession, C., Zhang, F., Regev, A., 2016. Div-Seq: Single-nucleus RNA-Seq reveals dynamics of rare adult newborn neurons. Science 353, 925-8. doi:10.1126/science.aad7038

Hajkova, P., Jeffries, S.J., Lee, C., Miller, N., Jackson, S.P., Surani, M.A., 2010. Genome-wide reprogramming in the mouse germ line entails the base excision repair pathway. Science 329, 78-82. doi:10.1126/science.1187945

Hammoud, S.S., Low, D.H.P., Yi, C., Carrell, D.T., Guccione, E., Cairns, B.R., Schübeler, D., Wirbelauer, C., Oakeley, E.J., Gaidatzis, D., al., et, 2014. Chromatin and Transcription Transitions of Mammalian Adult Germline Stem Cells and Spermatogenesis. Cell Stem Cell 15, 239-253. doi:10.1016/j.stem.2014.04.006

Hammoud, S.S., Low, D.H.P., Yi, C., Lee, C.L., Oatley, J.M., Payne, C.J., Carrell, D.T., Guccione, E., Cairns, B.R., 2015. Transcription and imprinting dynamics in developing postnatal male germline stem cells. Genes Dev. 29, 2312-24. doi:10.1101/gad.261925.115

Han, Y., Guo, S., Muegge, K., Zhang, W., Zhou, B., 2015. Advanced Applications of RNA Sequencing and Challenges. Bioinform. Biol. Insights 9, 29. doi:10.4137/BBI.S28991

Harcourt, A.H., Harvey, P.H., Larson, S.G., Short, R. V, 1981. Testis weight, body weight and breeding system in primates. Nature 293, 55-7.

Hardwick, S.A., Deveson, I.W., Mercer, T.R., 2017. Reference standards for next-generation sequencing. Nat. Rev. Genet. 18, 473-484. doi:10.1038/nrg.2017.44

Head, S.R., Komori, H.K., LaMere, S.A., Whisenant, T., Van Nieuwerburgh, F., Salomon, D.R., Ordoukhanian, P., 2014. Library construction for next-generation sequencing: overviews and challenges. Biotechniques 56, 61-4, 66, 68, passim. doi:10.2144/000114133

Heller, M.J., 2002. DNA Microarray Technology: Devices, Systems, and Applications. Annu. Rev. Biomed. Eng. 4, 129-153. doi:10.1146/annurev.bioeng.4.020702.153438

Helsel, A.R., Yang, Q.-E., Oatley, M.J., Lord, T., Sablitzky, F., Oatley, J.M., 2017. ID4 levels dictate the stem cell state in mouse spermatogonia. Development 144, 624-634. doi:10.1242/dev.146928

Hermann, B.P., Mutoji, K.N., Velte, E.K., Ko, D., Oatley, J.M., Geyer, C.B., McCarrey, J.R., 2015. Transcriptional and translational heterogeneity among neonatal mouse spermatogonia. Biol. Reprod. 92, 54. doi:10.1095/biolreprod.114.125757

Hou, Y., Guo, H., Cao, C., Li, X., Hu, B., Zhu, P., Wu, X., Wen, L., Tang, F., Huang, Y., Peng, J., 2016. Single-cell triple omics sequencing reveals genetic, epigenetic, and transcriptomic heterogeneity in hepatocellular carcinomas. Cell Res. 26, 304-319. doi:10.1038/cr.2016.23

Houmard, B., Small, C., Yang, L., Naluai-Cecchini, T., Cheng, E., Hassold, T., Griswold, M., 2009. Global Gene Expression in the Human Fetal Testis and Ovary. Biol Reprod 443, biolreprod.108.075747. doi:10.1095/biolreprod.108.075747

Hrdlickova, R., Toloue, M., Tian, B., 2017. RNA-Seq methods for transcriptome analysis. Wiley Interdiscip. Rev. RNA 8, e1364. doi:10.1002/wrna.1364

Huang, H.-C., Niu, Y., Qin, L.-X., 2015. Differential Expression Analysis for RNA-Seq: An Overview of Statistical Methods and Computational Software. Cancer Inform. 14, 57-67. 
doi:10.4137/CIN.S21631

Huang, S., Yang, B., Chen, B.J., Bliim, N., Ueberham, U., Arendt, T., Janitz, M., 2017. The emerging role of circular RNAs in transcriptome regulation. Genomics 109, 401-407. doi:10.1016/j.ygeno.2017.06.005

Huang, S., Zhang, J., Li, R., Zhang, W., He, Z., Lam, T.-W., Peng, Z., Yiu, S.-M., 2011. SOAPsplice: Genome-Wide ab initio Detection of Splice Junctions from RNA-Seq Data. Front. Genet. 2, 46. doi:10.3389/fgene.2011.00046

Ichijima, Y., Sin, H.-S., Namekawa, S.H., 2012. Sex chromosome inactivation in germ cells: emerging roles of DNA damage response pathways. Cell. Mol. Life Sci. 69, 2559-72. doi:10.1007/s00018012-0941-5

Idler, R.K., Yan, W., 2012. Control of messenger RNA fate by RNA-binding proteins: an emphasis on mammalian spermatogenesis. J. Androl. 33, 309-37. doi:10.2164/jandrol.111.014167

Irie, N., Weinberger, L., Tang, W.W.C., Kobayashi, T., Viukov, S., Manor, Y.S., Dietmann, S., Hanna, J.H., Surani, M.A., 2015. SOX17 is a critical specifier of human primordial germ cell fate. Cell 160, 253-268. doi:10.1016/j.cell.2014.12.013

Izadi, F., Zarrini, H.N., Kiani, G., Jelodar, N.B., 2016. A comparative analytical assay of gene regulatory networks inferred using microarray and RNA-seq datasets. Bioinformation 12, 340-346. doi:10.6026/97320630012340

Jacinto, F. V, Ballestar, E., Esteller, M., 2008. Methyl-DNA immunoprecipitation (MeDIP): hunting down the DNA methylome. Biotechniques 44, 35, 37, 39 passim.

Jaitin, D.A., Kenigsberg, E., Keren-Shaul, H., Elefant, N., Paul, F., Zaretsky, I., Mildner, A., Cohen, N., Jung, S., Tanay, A., Amit, I., 2014. Massively parallel single-cell RNA-seq for marker-free decomposition of tissues into cell types. Science 343, 776-9. doi:10.1126/science.1247651

Jameson, S.A., Natarajan, A., Cool, J., DeFalco, T., Maatouk, D.M., Mork, L., Munger, S.C., Capel, B., 2012. Temporal transcriptional profiling of somatic and germ cells reveals biased lineage priming of sexual fate in the fetal mouse gonad. PLoS Genet. 8, e1002575. doi:10.1371/journal.pgen.1002575

Jan, S.Z., Vormer, T.L., Jongejan, A., Röling, M., Silber, S.J., de Rooij, D.G., Hamer, G., Repping, S., van Pelt, A.M.M., 2017. Unraveling transcriptome dynamics in human spermatogenesis. Development dev.152413. doi:10.1242/dev.152413

Jégou, B., Sankararaman, S., Rolland, A.D., Reich, D., Chalmel, F., 2017. Meiotic Genes Are Enriched in Regions of Reduced Archaic Ancestry. Mol. Biol. Evol. 34, 1974-1980. doi:10.1093/molbev/msx141

Jin, S.-G., Wu, X., Li, A.X., Pfeifer, G.P., 2011. Genomic mapping of 5-hydroxymethylcytosine in the human brain. Nucleic Acids Res. 39, 5015-5024. doi:10.1093/nar/gkr120

Johnson, J.M., Castle, J., Garrett-Engele, P., Kan, Z., Loerch, P.M., Armour, C.D., Santos, R., Schadt, E.E., Stoughton, R., Shoemaker, D.D., 2003. Genome-wide survey of human alternative pre-mRNA splicing with exon junction microarrays. Science 302, 2141-4. doi:10.1126/science.1090100

Kalisky, T., Oriel, S., Bar-Lev, T.H., Ben-Haim, N., Trink, A., Wineberg, Y., Kanter, I., Gilad, S., Pyne, S., 2017. A brief review of single-cell transcriptomic technologies. Brief. Funct. Genomics. doi:10.1093/bfgp/elx019

Katz, Y., Wang, E.T., Airoldi, E.M., Burge, C.B., 2010. Analysis and design of RNA sequencing experiments for identifying isoform regulation. Nat. Methods 7, 1009-1015. doi:10.1038/nmeth.1528

Kelly, T.K., Liu, Y., Lay, F.D., Liang, G., Berman, B.P., Jones, P.A., 2012. Genome-wide mapping of nucleosome positioning and DNA methylation within individual DNA molecules. Genome Res. 22, 2497-2506. doi:10.1101/gr.143008.112

Klein, A.M., Mazutis, L., Akartuna, I., Tallapragada, N., Veres, A., Li, V., Peshkin, L., Weitz, D.A., Kirschner, M.W., 2015. Droplet Barcoding for Single-Cell Transcriptomics Applied to Embryonic Stem Cells. Cell 161, 1187-1201. doi:10.1016/j.cell.2015.04.044

Kolesnikov, N., Hastings, E., Keays, M., Melnichuk, O., Tang, Y.A., Williams, E., Dylag, M., Kurbatova, N., Brandizi, M., Burdett, T., Megy, K., Pilicheva, E., Rustici, G., Tikhonov, A., Parkinson, H., 
Petryszak, R., Sarkans, U., Brazma, A., 2015. ArrayExpress update-simplifying data submissions. Nucleic Acids Res. 43, D1113-D1116. doi:10.1093/nar/gku1057

Kotaja, N., Sassone-Corsi, P., 2007. The chromatoid body: a germ-cell-specific RNA-processing centre. Nat. Rev. Mol. Cell Biol. 8, 85-90. doi:10.1038/nrm2081

Kowalczykiewicz, D., Świercz, A., Handschuh, L., Leśniak, K., Figlerowicz, M., Wrzesinski, J., 2014. Characterization of Sus scrofa small non-coding RNAs present in both female and male gonads. PLoS One 9, e113249. doi:10.1371/journal.pone.0113249

Kubo, N., Toh, H., Shirane, K., Shirakawa, T., Kobayashi, H., Sato, T., Sone, H., Sato, Y., Tomizawa, S., Tsurusaki, Y., Shibata, H., Saitsu, H., Suzuki, Y., Matsumoto, N., Suyama, M., Kono, T., Ohbo, K., Sasaki, H., 2015. DNA methylation and gene expression dynamics during spermatogonial stem cell differentiation in the early postnatal mouse testis. BMC Genomics 16, 624. doi:10.1186/s12864-0151833-5

Kvam, V.M., Liu, P., Si, Y., 2012. A comparison of statistical methods for detecting differentially expressed genes from RNA-seq data. Am. J. Bot. 99, 248-56. doi:10.3732/ajb.1100340

Laiho, A., Kotaja, N., Gyenesei, A., Sironen, A., 2013. Transcriptome profiling of the murine testis during the first wave of spermatogenesis. PLoS One 8, e61558. doi:10.1371/journal.pone.0061558

Lake, B.B., Ai, R., Kaeser, G.E., Salathia, N.S., Yung, Y.C., Liu, R., Wildberg, A., Gao, D., Fung, H.-L., Chen, S., Vijayaraghavan, R., Wong, J., Chen, A., Sheng, X., Kaper, F., Shen, R., Ronaghi, M., Fan, J.-B., Wang, W., Chun, J., Zhang, K., 2016. Neuronal subtypes and diversity revealed by singlenucleus RNA sequencing of the human brain. Science 352, 1586-90. doi:10.1126/science.aaf1204

Laver, T., Harrison, J., O’Neill, P.A., Moore, K., Farbos, A., Paszkiewicz, K., Studholme, D.J., 2015. Assessing the performance of the Oxford Nanopore Technologies MinION. Biomol. Detect. Quantif. 3, 1-8. doi:10.1016/j.bdq.2015.02.001

Lee, T.-L., Cheung, H.-H., Claus, J., Sastry, C., Singh, S., Vu, L., Rennert, O., Chan, W.-Y., 2009. GermSAGE: a comprehensive SAGE database for transcript discovery on male germ cell development. Nucleic Acids Res. 37, D891-7. doi:10.1093/nar/gkn644

Lee, T.-L., Rennert, O.M., Chan, W.-Y., 2012. Revealing the transcriptome landscape of mouse spermatogonial cells by tiling microarray. Methods Mol. Biol. 825, 75-92. doi:10.1007/978-161779-436-0_7

Lesch, B.J., Dokshin, G.A., Young, R.A., McCarrey, J.R., Page, D.C., 2013. A set of genes critical to development is epigenetically poised in mouse germ cells from fetal stages through completion of meiosis. Proc. Natl. Acad. Sci. U. S. A. 110, 16061-6. doi:10.1073/pnas.1315204110

Li, L., Dong, J., Yan, L., Yong, J., Liu, X., Hu, Y., Fan, X., Wu, X., Guo, H., Wang, X., Zhu, X., Li, R., Yan, J., Wei, Y., Zhao, Y., Wang, W., Ren, Y., Yuan, P., Yan, Z., Hu, B., Guo, F., Wen, L., Tang, F., Qiao, J., 2017. Single-Cell RNA-Seq Analysis Maps Development of Human Germline Cells and Gonadal Niche Interactions. Cell Stem Cell 20, 891-892. doi:10.1016/j.stem.2017.05.009

Li, M., Liu, Y., Wang, T., Guan, J., Luo, Z., Chen, H., Wang, X., Chen, L., Ma, J., Mu, Z., Jiang, A., Zhu, L., Lang, Q., Zhou, X., Wang, J., Zeng, W., Li, N., Li, K., Gao, X., Li, X., 2011. Repertoire of porcine microRNAs in adult ovary and testis by deep sequencing. Int. J. Biol. Sci. 7, 1045-55.

Li, X., Ao, J., Wu, J., 2017. Systematic identification and comparison of expressed profiles of lncRNAs and circRNAs with associated co-expression and ceRNA networks in mouse germline stem cells. Oncotarget 8, 26573-26590. doi:10.18632/oncotarget.15719

Li, X.Z., Roy, C.K., Dong, X., Bolcun-Filas, E., Wang, J., Han, B.W., Xu, J., Moore, M.J., Schimenti, J.C., Weng, Z., Zamore, P.D., 2013. An ancient transcription factor initiates the burst of piRNA production during early meiosis in mouse testes. Mol. Cell 50, 67-81. doi:10.1016/j.molcel.2013.02.016

Li, Y., Li, J., Fang, C., Shi, L., Tan, J., Xiong, Y., Bin Fan, B., Li, C., 2016. Genome-wide differential expression of genes and small RNAs in testis of two different porcine breeds and at two different ages. Sci. Rep. 6, 26852. doi:10.1038/srep26852

Lian, C., Sun, B., Niu, S., Yang, R., Liu, B., Lu, C., Meng, J., Qiu, Z., Zhang, L., Zhao, Z., 2012. A comparative profile of the microRNA transcriptome in immature and mature porcine testes using 
Solexa deep sequencing. FEBS J. 279, 964-75. doi:10.1111/j.1742-4658.2012.08480.x

Lin, X., Han, M., Cheng, L., Chen, J., Zhang, Z., Shen, T., Wang, M., Wen, B., Ni, T., Han, C., 2016. Expression dynamics, relationships, and transcriptional regulations of diverse transcripts in mouse spermatogenic cells. RNA Biol. 13, 1011-1024. doi:10.1080/15476286.2016.1218588

Liu, G., Lei, B., Li, Y., Tong, K., Ding, Y., Luo, L., Xia, X., Jiang, S., Deng, C., Xiong, Y., Li, F., 2012. Discovery of potential piRNAs from next generation sequences of the sexually mature porcine testes. PLoS One 7, e34770. doi:10.1371/journal.pone.0034770

Lord, T., Oatley, J.M., 2017. A revised Asingle model to explain stem cell dynamics in the mouse male germline. Reproduction 154, R55-R64. doi:10.1530/REP-17-0034

Lu, H., Giordano, F., Ning, Z., 2016. Oxford Nanopore MinION Sequencing and Genome Assembly. Genomics. Proteomics Bioinformatics 14, 265-279. doi:10.1016/j.gpb.2016.05.004

Luk, A.C.-S., Chan, W.-Y., Rennert, O.M., Lee, T.-L., 2014. Long noncoding RNAs in spermatogenesis: insights from recent high-throughput transcriptome studies. Reproduction 147, R131-41. doi:10.1530/REP-13-0594

Luk, A.C.-S., Gao, H., Xiao, S., Liao, J., Wang, D., Tu, J., Rennert, O.M., Chan, W.-Y., Lee, T.-L., 2015. GermlncRNA: a unique catalogue of long non-coding RNAs and associated regulations in male germ cell development. Database (Oxford). 2015, bav044. doi:10.1093/database/bav044

Luo, L.-F., Hou, C.-C., Yang, W.-X., 2016. Small non-coding RNAs and their associated proteins in spermatogenesis. Gene 578, 141-157. doi:10.1016/j.gene.2015.12.020

20 Luo, Z., Liu, Y., Chen, L., Ellis, M., Li, M., Wang, J., Zhang, Y., Fu, P., Wang, K., Li, X., Wang, L., 2015. microRNA profiling in three main stages during porcine spermatogenesis. J. Assist. Reprod. Genet. 32, 451-60. doi:10.1007/s10815-014-0406-x

Macaulay, I.C., Ponting, C.P., Voet, T., 2017. Single-Cell Multiomics: Multiple Measurements from Single Cells. Trends Genet. 33, 155-168. doi:10.1016/j.tig.2016.12.003

25 Macosko, E.Z., Basu, A., Satija, R., Nemesh, J., Shekhar, K., Goldman, M., Tirosh, I., Bialas, A.R., Kamitaki, N., Martersteck, E.M., Trombetta, J.J., Weitz, D.A., Sanes, J.R., Shalek, A.K., Regev, A., McCarroll, S.A., 2015. Highly Parallel Genome-wide Expression Profiling of Individual Cells Using Nanoliter Droplets. Cell 161, 1202-1214. doi:10.1016/j.cell.2015.05.002

Malone, J.H., Oliver, B., 2011. Microarrays, deep sequencing and the true measure of the transcriptome. BMC Biol. 9, 34. doi:10.1186/1741-7007-9-34

Margolin, G., Khil, P.P., Kim, J., Bellani, M.A., Camerini-Otero, R.D., 2014. Integrated transcriptome analysis of mouse spermatogenesis. BMC Genomics 15, 39. doi:10.1186/1471-2164-15-39

McClelland, K.S., Bell, K., Larney, C., Harley, V.R., Sinclair, A.H., Oshlack, A., Koopman, P., Bowles, J., 2015. Purification and Transcriptomic Analysis of Mouse Fetal Leydig Cells Reveals Candidate Genes for Specification of Gonadal Steroidogenic Cells1. Biol. Reprod. 92, 1-12. doi:10.1095/biolreprod.115.128918

McKenna, A., Findlay, G.M., Gagnon, J.A., Horwitz, M.S., Schier, A.F., Shendure, J., 2016. Wholeorganism lineage tracing by combinatorial and cumulative genome editing. Science (80-. ). 353, aaf7907. doi:10.1126/science.aaf7907

Meikar, O., Da Ros, M., Korhonen, H., Kotaja, N., 2011. Chromatoid body and small RNAs in male germ cells. Reproduction 142, 195-209. doi:10.1530/REP-11-0057

Meikar, O., Vagin, V. V, Chalmel, F., Sõstar, K., Lardenois, A., Hammell, M., Jin, Y., Da Ros, M., Wasik, K.A., Toppari, J., Hannon, G.J., Kotaja, N., 2014. An atlas of chromatoid body components. RNA 20, 483-95. doi:10.1261/rna.043729.113

Meng, X., Liu, P., Jia, F., Li, J., Gao, B.-Q., 2015. De novo Transcriptome Analysis of Portunus trituberculatus Ovary and Testis by RNA-Seq: Identification of Genes Involved in Gonadal Development. PLoS One 10, e0128659. doi:10.1371/journal.pone.0128659

Mensaert, K., Denil, S., Trooskens, G., Van Criekinge, W., Thas, O., De Meyer, T., 2014. Next-generation technologies and data analytical approaches for epigenomics. Environ. Mol. Mutagen. 55, 155-170. doi:10.1002/em.21841

Mockler, T.C., Ecker, J.R., Sundaresan, A., Chen, H., Jacobsen, S.E., Ecker, J.R., 2005. Applications of 
DNA tiling arrays for whole-genome analysis. Genomics 85, 1-15. doi:10.1016/j.ygeno.2004.10.005

Morozova, O., Hirst, M., Marra, M.A., 2009. Applications of New Sequencing Technologies for Transcriptome Analysis. Annu. Rev. Genomics Hum. Genet. 10, 135-151. doi:10.1146/annurevgenom-082908-145957

Munger, S.C., Natarajan, A., Looger, L.L., Ohler, U., Capel, B., 2013. Fine Time Course Expression Analysis Identifies Cascades of Activation and Repression and Maps a Putative Regulator of Mammalian Sex Determination. PLoS Genet. 9, e1003630. doi:10.1371/journal.pgen.1003630

Mutoji, K., Singh, A., Nguyen, T., Gildersleeve, H., Kaucher, A. V., Oatley, M.J., Oatley, J.M., Velte, E.K., Geyer, C.B., Cheng, K., McCarrey, J.R., Hermann, B.P., 2016. TSPAN8 Expression Distinguishes Spermatogonial Stem Cells in the Prepubertal Mouse Testis. Biol. Reprod. 95, 117117. doi:10.1095/biolreprod.116.144220

Naro, C., Jolly, A., Di Persio, S., Bielli, P., Setterblad, N., Alberdi, A.J., Vicini, E., Geremia, R., De la Grange, P., Sette, C., 2017. An Orchestrated Intron Retention Program in Meiosis Controls Timely Usage of Transcripts during Germ Cell Differentiation. Dev. Cell 41, 82-93.e4. doi:10.1016/j.devcel.2017.03.003

Necsulea, A., Soumillon, M., Warnefors, M., Liechti, A., Daish, T., Zeller, U., Baker, J.C., Grützner, F., Kaessmann, H., 2014. The evolution of lncRNA repertoires and expression patterns in tetrapods. Nature 505, 635-40. doi:10.1038/nature12943

Nelson, N.J., 2001. Microarrays have arrived: gene expression tool matures. J. Natl. Cancer Inst. 93, 4924.

Nguyen, M.T., Delaney, D.P., Kolon, T.F., 2009. Gene expression alterations in cryptorchid males using spermatozoal microarray analysis. Fertil. Steril. 92, 182-187. doi:10.1016/j.fertnstert.2008.05.043

Niu, Z., Goodyear, S.M., Rao, S., Wu, X., Tobias, J.W., Avarbock, M.R., Brinster, R.L., 2011. MicroRNA-21 regulates the self-renewal of mouse spermatogonial stem cells. Proc. Natl. Acad. Sci. U. S. A. 108, 12740-5. doi:10.1073/pnas.1109987108

O’Neil, S.T., Emrich, S.J., 2013. Assessing De Novo transcriptome assembly metrics for consistency and utility. BMC Genomics 14, 465. doi:10.1186/1471-2164-14-465

Oakberg, E.F., 1957. Duration of spermatogenesis in the mouse. Nature 180, 1137-8.

Oakberg, E.F., 1956. Duration of spermatogenesis in the mouse and timing of stages of the cycle of the seminiferous epithelium. Am. J. Anat. 99, 507-516. doi:10.1002/aja.1000990307

Oatley, M.J., Kaucher, A. V., Racicot, K.E., Oatley, J.M., 2011. Inhibitor of DNA Binding 4 Is Expressed Selectively by Single Spermatogonia in the Male Germline and Regulates the Self-Renewal of Spermatogonial Stem Cells in Mice1. Biol. Reprod. 85, 347-356. doi:10.1095/biolreprod.111.091330

Okada, H., Tajima, A., Shichiri, K., Tanaka, A., Tanaka, K., Inoue, I., 2008. Genome-Wide Expression of Azoospermia Testes Demonstrates a Specific Profile and Implicates ART3 in Genetic Susceptibility. PLoS Genet. 4, e26. doi:10.1371/journal.pgen.0040026

Orwig, K.E., Ryu, B.-Y., Master, S.R., Phillips, B.T., Mack, M., Avarbock, M.R., Chodosh, L., Brinster, R.L., 2008. Genes Involved in Post-Transcriptional Regulation Are Overrepresented in Stem/Progenitor Spermatogonia of Cryptorchid Mouse Testes. Stem Cells 26, 927-938. doi:10.1634/stemcells.2007-0893

Park, P.J., 2009. ChIP-seq: advantages and challenges of a maturing technology. Nat. Rev. Genet. 10, 669-80. doi:10.1038/nrg2641

Paronetto, M.P., Sette, C., 2010. Role of RNA-binding proteins in mammalian spermatogenesis. Int. J. Androl. 33, 2-12. doi:10.1111/j.1365-2605.2009.00959.x

Parvinen, M., 2005. The chromatoid body in spermatogenesis. Int. J. Androl. 28, 189-201. doi:10.1111/j.1365-2605.2005.00542.x

Perli, S.D., Cui, C.H., Lu, T.K., 2016. Continuous genetic recording with self-targeting CRISPR-Cas in human cells. Science 353. doi:10.1126/science.aag0511

Peruquetti, R.L., 2015. Perspectives on mammalian chromatoid body research. Anim. Reprod. Sci. 159, 816. doi:10.1016/j.anireprosci.2015.05.018 
Popp, C., Dean, W., Feng, S., Cokus, S.J., Andrews, S., Pellegrini, M., Jacobsen, S.E., Reik, W., 2010. Genome-wide erasure of DNA methylation in mouse primordial germ cells is affected by AID deficiency. Nature 463, 1101-5. doi:10.1038/nature08829

Pozhitkov, A.E., Tautz, D., Noble, P.A., 2007. Oligonucleotide microarrays: widely applied poorly understood. Briefings Funct. Genomics Proteomics 6, 141-148. doi:10.1093/bfgp/elm014

Ramsköld, D., Wang, E.T., Burge, C.B., Sandberg, R., 2009. An Abundance of Ubiquitously Expressed Genes Revealed by Tissue Transcriptome Sequence Data. PLoS Comput. Biol. 5, e1000598. doi:10.1371/journal.pcbi.1000598

Rastetter, R.H., Smith, C.A., Wilhelm, D., 2015. The role of non-coding RNAs in male sex determination and differentiation. Reproduction 150, R93-107. doi:10.1530/REP-15-0106

Rhoads, A., Au, K.F., 2015. PacBio Sequencing and Its Applications. Genomics. Proteomics Bioinformatics 13, 278-89. doi:10.1016/j.gpb.2015.08.002

Rockett, J.C., Christopher Luft, J., Brian Garges, J., Krawetz, S.A., Hughes, M.R., Hee Kirn, K., Oudes, A.J., Dix, D.J., 2001. Development of a 950-gene DNA array for examining gene expression patterns in mouse testis. Genome Biol. 2, RESEARCH0014.

Rybak-Wolf, A., Stottmeister, C., Glažar, P., Jens, M., Pino, N., Giusti, S., Hanan, M., Behm, M., Bartok, O., Ashwal-Fluss, R., Herzog, M., Schreyer, L., Papavasileiou, P., Ivanov, A., Öhman, M., Refojo, D., Kadener, S., Rajewsky, N., 2015. Circular RNAs in the Mammalian Brain Are Highly Abundant, Conserved, and Dynamically Expressed. Mol. Cell 58, 870-85. doi:10.1016/j.molcel.2015.03.027

Sankararaman, S., Mallick, S., Dannemann, M., Prüfer, K., Kelso, J., Pääbo, S., Patterson, N., Reich, D., 2014. The genomic landscape of Neanderthal ancestry in present-day humans. Nature 507, 354-357. doi:10.1038/nature12961

Sankararaman, S., Mallick, S., Patterson, N., Reich, D., 2016. The Combined Landscape of Denisovan and Neanderthal Ancestry in Present-Day Humans. Curr. Biol. 26, 1241-1247. doi:10.1016/j.cub.2016.03.037

Satija, R., Farrell, J.A., Gennert, D., Schier, A.F., Regev, A., 2015. Spatial reconstruction of single-cell gene expression data. Nat. Biotechnol. 33, 495-502. doi:10.1038/nbt.3192

Schena, M., Shalon, D., Davis, R.W., Brown, P.O., 1995. Quantitative monitoring of gene expression patterns with a complementary DNA microarray. Science 270, 467-70.

Schmid, R., Grellscheid, S.N., Ehrmann, I., Dalgliesh, C., Danilenko, M., Paronetto, M.P., Pedrotti, S., Grellscheid, D., Dixon, R.J., Sette, C., Eperon, I.C., Elliott, D.J., 2013. The splicing landscape is globally reprogrammed during male meiosis. Nucleic Acids Res. 41, 10170-84. doi:10.1093/nar/gkt811

Schmidt, S.T., Zimmerman, S.M., Wang, J., Kim, S.K., Quake, S.R., 2017. Quantitative Analysis of Synthetic Cell Lineage Tracing Using Nuclease Barcoding. ACS Synth. Biol. 6, 936-942. doi:10.1021/acssynbio.6b00309

Schuster, A., Tang, C., Xie, Y., Ortogero, N., Yuan, S., Yan, W., 2016. SpermBase: A Database for Sperm-Borne RNA Contents. Biol. Reprod. 95, 99-99. doi:10.1095/biolreprod.116.142190

Seisenberger, S., Andrews, S., Krueger, F., Arand, J., Walter, J., Santos, F., Popp, C., Thienpont, B., Dean, W., Reik, W., 2012. The dynamics of genome-wide DNA methylation reprogramming in mouse primordial germ cells. Mol. Cell 48, 849-62. doi:10.1016/j.molcel.2012.11.001

Seki, Y., Hayashi, K., Itoh, K., Mizugaki, M., Saitou, M., Matsui, Y., 2005. Extensive and orderly reprogramming of genome-wide chromatin modifications associated with specification and early development of germ cells in mice. Dev. Biol. 278, 440-58. doi:10.1016/j.ydbio.2004.11.025

Skylaki, S., Hilsenbeck, O., Schroeder, T., 2016. Challenges in long-term imaging and quantification of single-cell dynamics. Nat. Biotechnol. 34, 1137-1144. doi:10.1038/nbt.3713

Small, C.L., Shima, J.E., Uzumcu, M., Skinner, M.K., Griswold, M.D., 2005. Profiling Gene Expression During the Differentiation and Development of the Murine Embryonic Gonad 72, 492-501. doi:10.1095/biolreprod.104.033696

Song, J.L., Nigam, P., Tektas, S.S., Selva, E., 2015. microRNA regulation of Wnt signaling pathways in development and disease. Cell. Signal. 27, 1380-91. doi:10.1016/j.cellsig.2015.03.018 
Soumillon, M., Necsulea, A., Weier, M., Brawand, D., Zhang, X., Gu, H., Barthès, P., Kokkinaki, M., Nef, S., Gnirke, A., Dym, M., deMassy, B., Mikkelsen, T.S., Kaessmann, H., 2013. Cellular Source and Mechanisms of High Transcriptome Complexity in the Mammalian Testis. Cell Rep. 3, 21792190. doi:10.1016/j.celrep.2013.05.031

Spiess, A.-N., Feig, C., Schulze, W., Chalmel, F., Cappallo-Obermann, H., Primig, M., Kirchhoff, C., 2007. Cross-platform gene expression signature of human spermatogenic failure reveals inflammatory-like response. Hum. Reprod. 22, 2936-2946. doi:10.1093/humrep/dem292

Stévant, I., Neirijnck, Y., Borel, C., Escoffier, J., Smith, L.B., Antonarakis, S.E., Dermitzakis, E.T., Nef, S., 2018. Deciphering Cell Lineage Specification during Male Sex Determination with Single-Cell RNA Sequencing. Cell Rep. 22, 1589-1599. doi:10.1016/j.celrep.2018.01.043

Sun, J., Lin, Y., Wu, J., 2013. Long non-coding RNA expression profiling of mouse testis during postnatal development. PLoS One 8, e75750. doi:10.1371/journal.pone.0075750

Tan, T., Zhang, Y., Ji, W., Zheng, P., 2014. miRNA signature in mouse spermatogonial stem cells revealed by high-throughput sequencing. Biomed Res. Int. 2014, 154251. doi:10.1155/2014/154251

Tanay, A., Regev, A., 2017. Scaling single-cell genomics from phenomenology to mechanism. Nature 541, 331-338. doi:10.1038/nature21350

Tang, W.W.C., Dietmann, S., Irie, N., Leitch, H.G., Floros, V.I., Bradshaw, C.R., Hackett, J.A., Chinnery, P.F., Surani, M.A., 2015. A Unique Gene Regulatory Network Resets the Human Germline Epigenome for Development. Cell 161, 1453-1467. doi:10.1016/j.cell.2015.04.053

20 Taylor, D.H., Chu, E.T.-J., Spektor, R., Soloway, P.D., 2015. Long non-coding RNA regulation of reproduction and development. Mol. Reprod. Dev. 82, 932-56. doi:10.1002/mrd.22581

van der Heijden, G.W., Eijpe, M., Baarends, W.M., 2011. The X and Y chromosome in meiosis: how and why they keep silent. Asian J. Androl. 13, 779-80. doi:10.1038/aja.2011.93

Velculescu, V.E., Zhang, L., Vogelstein, B., Kinzler, K.W., 1995. Serial analysis of gene expression. Science 270, 484-7.

Venables, J.P., 2002. Alternative splicing in the testes. Curr. Opin. Genet. Dev. 12, 615-19.

von Kopylow, K., Kirchhoff, C., Jezek, D., Schulze, W., Feig, C., Primig, M., Steinkraus, V., Spiess, A.N., 2010. Screening for biomarkers of spermatogonia within the human testis: a whole genome approach. Hum. Reprod. 25, 1104-1112. doi:10.1093/humrep/deq053

von Meyenn, F., Berrens, R. V, Andrews, S., Santos, F., Collier, A.J., Krueger, F., Osorno, R., Dean, W., Rugg-Gunn, P.J., Reik, W., 2016. Comparative Principles of DNA Methylation Reprogramming during Human and Mouse In Vitro Primordial Germ Cell Specification. Dev. Cell 39, 104-115. doi:10.1016/j.devcel.2016.09.015

Vourekas, A., Zheng, Q., Alexiou, P., Maragkakis, M., Kirino, Y., Gregory, B.D., Mourelatos, Z., 2012. Mili and Miwi target RNA repertoire reveals piRNA biogenesis and function of Miwi in spermiogenesis. Nat. Struct. Mol. Biol. 19, 773-81. doi:10.1038/nsmb.2347

Wagner, A., Regev, A., Yosef, N., 2016. Revealing the vectors of cellular identity with single-cell genomics. Nat. Biotechnol. 34, 1145-1160. doi:10.1038/nbt.3711

Walker, W.H., Delfino, F.J., Habener, J.F., 1999. RNA processing and the control of spermatogenesis. Front. Horm. Res. 25, 34-58.

Wang, C., Gong, B., Bushel, P.R., Thierry-Mieg, J., Thierry-Mieg, D., Xu, J., Fang, H., Hong, H., Shen, J., Su, Z., Meehan, J., Li, X., Yang, L., Li, H., Labaj, P.P., Kreil, D.P., Megherbi, D., Gaj, S., Caiment, F., van Delft, J., Kleinjans, J., Scherer, A., Devanarayan, V., Wang, J., Yang, Y., Qian, H.R., Lancashire, L.J., Bessarabova, M., Nikolsky, Y., Furlanello, C., Chierici, M., Albanese, D., Jurman, G., Riccadonna, S., Filosi, M., Visintainer, R., Zhang, K.K., Li, J., Hsieh, J.-H., Svoboda, D.L., Fuscoe, J.C., Deng, Y., Shi, L., Paules, R.S., Auerbach, S.S., Tong, W., 2014. The concordance between RNA-seq and microarray data depends on chemical treatment and transcript abundance. Nat. Biotechnol. 32, 926-32. doi:10.1038/nbt.3001

Wang, K.C., Chang, H.Y., 2011. Molecular Mechanisms of Long Noncoding RNAs. Mol. Cell 43, 904914. doi:10.1016/j.molcel.2011.08.018

Wang, Z., Gerstein, M., Snyder, M., 2009. RNA-Seq: a revolutionary tool for transcriptomics. Nat. Rev. 
Genet. 10, 57-63. doi:10.1038/nrg2484

Wichman, L., Somasundaram, S., Breindel, C., Valerio, D.M., McCarrey, J.R., Hodges, C.A., Khalil, A.M., 2017. Dynamic expression of long noncoding RNAs reveals their potential roles in spermatogenesis and fertility. Biol. Reprod. 97, 313-323. doi:10.1093/biolre/iox084

Wu, Z., Wu, H., 2016. Experimental Design and Power Calculation for RNA-seq Experiments. Humana Press, New York, NY, pp. 379-390. doi:10.1007/978-1-4939-3578-9_18

Yadav, R.P., Kotaja, N., 2014. Small RNAs in spermatogenesis. Mol. Cell. Endocrinol. 382, 498-508. doi:10.1016/j.mce.2013.04.015

Yang, Q., Hua, J., Wang, L., Xu, B., Zhang, H., Ye, N., Zhang, Z., Yu, D., Cooke, H.J., Zhang, Y., Shi, Q., 2013. MicroRNA and piRNA profiles in normal human testis detected by next generation sequencing. PLoS One 8, e66809. doi:10.1371/journal.pone.0066809

Yuan, G.-C., Cai, L., Elowitz, M., Enver, T., Fan, G., Guo, G., Irizarry, R., Kharchenko, P., Kim, J., Orkin, S., Quackenbush, J., Saadatpour, A., Schroeder, T., Shivdasani, R., Tirosh, I., 2017. Challenges and emerging directions in single-cell analysis. Genome Biol. 18, 84. doi:10.1186/s13059-017-1218-y

Zhang, P., Kang, J.-Y., Gou, L.-T., Wang, J., Xue, Y., Skogerboe, G., Dai, P., Huang, D.-W., Chen, R., Fu, X.-D., Liu, M.-F., He, S., 2015. MIWI and piRNA-mediated cleavage of messenger RNAs in mouse testes. Cell Res. 25, 193-207. doi:10.1038/cr.2015.4

Zhu, Z.-J., Yang, S., Li, Z., 2015. Transcriptome research on spermatogenic molecular drive in mammals. Asian J. Androl. 17, 961-71. doi:10.4103/1008-682X.159721

Zhu, Z., Li, C., Yang, S., Tian, R., Wang, J., Yuan, Q., Dong, H., He, Z., Wang, S., Li, Z., 2016. Dynamics of the Transcriptome during Human Spermatogenesis: Predicting the Potential Key Genes Regulating Male Gametes Generation. Sci. Rep. 6, 19069. doi:10.1038/srep19069

Ziegenhain, C., Vieth, B., Parekh, S., Reinius, B., Guillaumet-Adkins, A., Smets, M., Leonhardt, H.,

25 Heyn, H., Hellmann, I., Enard, W., 2017. Comparative Analysis of Single-Cell RNA Sequencing Methods. Mol. Cell 65, 631-643.e4. doi:10.1016/j.molcel.2017.01.023

Zilionis, R., Nainys, J., Veres, A., Savova, V., Zemmour, D., Klein, A.M., Mazutis, L., 2016. Single-cell barcoding and sequencing using droplet microfluidics. Nat. Protoc. 12, 44-73. doi:10.1038/nprot.2016.154

Zimmermann, C., Stévant, I., Borel, C., Conne, B., Pitetti, J.-L., Calvel, P., Kaessmann, H., Jégou, B., Chalmel, F., Nef, S., 2015. Research Resource: The Dynamic Transcriptional Profile of Sertoli Cells During the Progression of Spermatogenesis. Mol. Endocrinol. 29, 627-642. doi:10.1210/me.20141356 